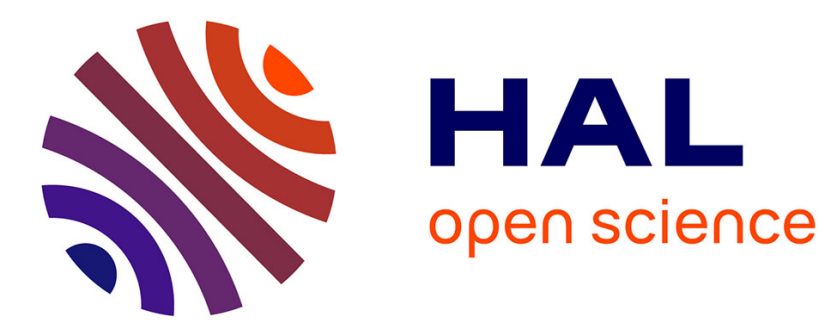

\title{
Magma storage conditions of the last eruption of Teide volcano (Canary Islands, Spain)
}

\author{
Joan Andújar, Fidel Costa Rodriguez, J. Marti
}

\section{To cite this version:}

Joan Andújar, Fidel Costa Rodriguez, J. Marti. Magma storage conditions of the last eruption of Teide volcano (Canary Islands, Spain). Bulletin of Volcanology / Bull Volcanic Eruptions, 2010, 72, pp.381-395. 10.1007/s00445-009-0325-3 . insu-00447691

\section{HAL Id: insu-00447691 https://hal-insu.archives-ouvertes.fr/insu-00447691}

Submitted on 18 Jan 2010

HAL is a multi-disciplinary open access archive for the deposit and dissemination of scientific research documents, whether they are published or not. The documents may come from teaching and research institutions in France or abroad, or from public or private research centers.
L'archive ouverte pluridisciplinaire HAL, est destinée au dépôt et à la diffusion de documents scientifiques de niveau recherche, publiés ou non, émanant des établissements d'enseignement et de recherche français ou étrangers, des laboratoires publics ou privés. 


\section{Magma storage conditions of the last eruption of Teide volcano (Canary Islands, Spain)}

Andújar, J. ${ }^{*}$, a, Costa, F ${ }^{\mathrm{a}}$, Martí, J. ${ }^{\mathrm{a}}$

a. Institute of Earth Sciences "Jaume Almera", CSIC, C/ Lluis Solé I Sabaris, s/n Barcelona, 08028 Spain.

* Corresponding author:

Andújar, J. Institute of Earth Sciences "Jaume Almera", CSIC, Barcelona.

Phone number: (+34) 934095410

Fax: (+34) 934110012

e-mail address: jandujar@ija.csic.es

Currently at: Institut des Sciences de la Terre (ISTO-CNRS). 1A, rue de la Ferrollerie, 45071 Orléans Cedex 2, France. e-mail address : Juan.Andujar@cnrsorleans.fr

Costa, F. E-mail address: fcosta@,ija.csic.es

Martí, J. E-mail address: joan.marti@ija.csic.es

Keywords: petrology, geophysics, phonolite, experiments, Tenerife. 


\section{Abstract}

Phase equilibrium experiments were performed to determine the pre-eruptive conditions of the phonolitic magma responsible for the last eruption (about $1150 \mathrm{yr}$ B.P.) of Teide volcano. The Lavas Negras phonolite contains 30 to $40 \mathrm{wt} \%$ of phenocrysts, mainly anorthoclase, diopside, and magnetite. We have investigated pressures from 100 to 250 $\mathrm{MPa}$, temperatures from 750 to $925^{\circ} \mathrm{C}$, water contents from 1.3 to $10 \mathrm{wt} \%$, at an oxygen fugacity $\left(f \mathrm{O}_{2}\right)$ of $1 \mathrm{log}$ unit above the $\mathrm{Ni}-\mathrm{NiO}$ solid buffer. Comparison of the natural and experimental phase proportions and compositions indicates that the phonolite was stored at $900 \pm 20^{\circ} \mathrm{C}, 150 \pm 50 \mathrm{MPa}, 3 \pm 0.5 \mathrm{wt} \%$ dissolved $\mathrm{H}_{2} \mathrm{O}$ in the melt. The $f \mathrm{O}_{2}$ was probably close to the fayalite-magnetite-quartz solid buffer judging from results of other experimental studies. These conditions constrain the magma storage depth at about $5 \pm 1 \mathrm{~km}$ below current summit of Teide volcano. Given that the island has not suffered any major structural or topographic changes since the Lavas Negras eruption, any remaining magma from this event should still be stored at such depth and probably with a similar thermal and rheological state. 


\section{Introduction}

In the Canary Islands (Spain), Teide volcano on Tenerife represents the major potential volcanic hazard to the region (e.g., Martí et al. 2008). The possibility of Teide reawakening has been recently brought to the forefront by increased onshore seismic activity in April 2004, which marked the first documented renewal of tectonic unrest on Tenerife (e.g., Martí et al. 2009). The last volcanic activity of Teide occurred in 1150 B.P. (calibrated age; Carracedo et al. 2007) and consisted of the effusive eruption of phonolitic lavas (Lavas Negras) with a volume of $\sim 0.5 \mathrm{~km}^{3}$. The recent geological record also includes some explosive phonolitic events from the Teide satellite vent systems like the 2000 B.P. subplinian eruption of Montaña Blanca (Ablay et al. 1995). An eruption on Teide today would have a major societal and economic impact, and thus it is important to have quantitative constraints on the variables characterizing the environment of magma storage at depth to be able to propose scenarios of future activity.

The stratigraphy and petrology of Teide volcano has been characterized in previous studies (e.g., Ablay et al. 1998; Ablay and Martí 2000). There is also a growing calibrated temporal framework of eruptive events that can be used to gain insights into the possible types of future activity (e.g., Carracedo et al. 2007). However, current knowledge of the storage conditions (e.g., depth of the reservoir, temperature, and volatile content) of the magmas beneath Teide is still very poor. To fill this gap we have performed an experimental and petrological study of the Lavas Negras phonolitic rocks.

\section{Volcanological background}


The evolution of volcanic activity on Tenerife can be summarized as: (1) a basaltic shield that forms about the $90 \%$ of the island and is still growing through two main rift zones (Abdel-Monen et al. 1972; Ancochea et al. 1990; Thirlwall et al. 2000), (2) a Central Complex (> 3.5 Ma to present, Fúster et al. 1968; Araña 1971; Ancochea et al. 1990; Martí et al. 1994), which comprises the Las Cañadas edifice (> 3.5 to $0.19 \mathrm{Ma}$ ), a composite basaltic to phonolitic volcano with abundant explosive eruptions and up to three caldera collapse episodes (Martí et al. 1994, 1997; Martí and Gudmundsson 2000), and (3) the currently active Teide and Pico Viejo stratovolcanos (0.19 Ma to present).

The Teide-Pico Viejo volcanic complex lies inside the Las Cañadas caldera and consists of two twin stratocones, numerous satellite vents, and outflow lavas that partially infill Las Cañadas Caldera and the adjacent La Orotava and Icod valleys (Hausen 1956; Araña 1971; Ablay 1997; Ablay et al. 1998; Ablay and Martí 2000; Carracedo et al. 2007). Eruption of mafic to intermediate magmas has dominated the early stages of Teide-Pico Viejo complex. Phonolitic compositions began erupting about 35 ka ago and have become predominant since then (Ablay and Martí 2000; Martí et al. 2008). Eruptive activity has alternated between Teide, and Pico Viejo in the recent history of the complex (Ablay et al. 1998; Ablay and Martí 2000; Martí et al. 2008).

The Lavas Negras eruption occurred from the central vent of Teide about 1150 years ago, and produced about $0.5 \mathrm{~km}^{3}$ of lavas and agglutinates which make up the current summit of Teide (Fig. 1; Ablay and Martí 2000). The unit occurs on the south and north flanks of Teide volcano, comprises many thick, blocky flows of melanocratic, glassy, porphyritic phonolite lava (Fig. 1). The phenocryst content of the Lavas Negras flows varies between 30 to $40 \mathrm{wt} \%$, and the bulk rock compositions of 14 samples from 
different locations are very similar, with variations of less than $3 \%$ relative for all major elements (Ablay 1997).

\section{Petrologic observations, geothermo-barometric data and sampling}

There are no previous constraints on the pre-eruptive conditions of the Lavas Negras magma. The storage conditions from the Montaña Blanca and Arenas Blancas phonolites have been obtained using various geothermometers and geobarometers (e.g., Ablay 1997; Ablay et al. 1998; Neumann et al. 1999). Coexisting Fe-Ti oxides yield temperatures of $750-860^{\circ} \mathrm{C}$ with an oxygen fugacity $\left(f \mathrm{O}_{2}\right)$ close to the fayalitemagnetite-quartz solid buffer (FMQ). Geobarometry calculations of the Lavas Negras using the Al content in clinopyroxenes as described in Grove et al. (1989) yield pressures of $\sim 200 \pm 100 \mathrm{MPa}$. We have used these conditions to guide our experimental work.

In order to obtain constraints on the pre-eruptive temperature and pressure conditions and volatile content of the Lavas Negras magma, we performed phase equilibrium experiments similar to those used to gain insight to the Mount St. Helens and Mount Pinatubo magmatic systems. See Pichavant et al. (2007) for a discussion of the application of phase equilibrium experiments to constrain pre-eruptive conditions. We used the freshest available rock as starting material for our experiments. It was collected from the western flank of Teide volcano at an altitude of about $3200 \mathrm{~m}$ and is lithologically and compositionally representative of the Lavas Negras lava flows. Modal point counting of one thin section (1500 points) was combined with mineral densities to obtain wt\% of the phenocrysts (crystals $>0.3 \mathrm{~mm}$ in longest dimension). The sample contained $\sim 37 \mathrm{wt} \%$ phenocrysts, mainly euhedral to subhedral anorthoclase 
$(\sim 32 \mathrm{wt} \%)$, clinopyroxene $(\sim 2 \mathrm{wt} \%)$, and magnetite $(\sim 3 \mathrm{wt} \%)$. The phenocrysts are set in a groundmass of poorly vesiculated glass and microlites of alkali feldspar, magnetite, clinopyroxene, and apatite (Fig. 2; Table 1).

\section{Experimental work}

\section{Starting material}

The finely ground phonolite sample was first melted in a Pt crucible at $1400^{\circ} \mathrm{C}$, in air, for 5 hours, in a 1 atmosphere vertical furnace at Dipartimento di Scienze della Terra, Università di Camerino (Italy). The high oxidizing conditions minimized any Fe loss to the Pt crucible (e.g., Johannes and Bode 1978) and at the same time set almost all $\mathrm{Fe}$ of the starting glass as $\mathrm{Fe}^{3+}$. The sample was quenched in a water container at room temperature. The resulting glass was examined under the binocular and Scanning Electron Microscope (SEM) to ensure the absence of crystals. Electron microprobe analysis of the glass showed that it is homogeneous with somewhat lower Si, slightly higher $\mathrm{Al}$ and $\mathrm{Ti}$ content, but about the same $\mathrm{Na}$ and Fe content as the bulk-rock composition determined by X-ray Fluorescence (XRF; Table 1). This shows that there were no significant $\mathrm{Na}$ or Fe loss during the preparation of the starting material. The finely ground glass was used as starting material in all experiments.

Experimental equipment and procedures

In total, 32 crystallization experiments (Table 2) were performed at the SIMGEO laboratory (Barcelona, Spain) using vertical (Nimonic 105 alloy) cold-seal pressure 
vessels (CSPV) connected to a $30 \mathrm{~cm}$ stainless steel extension and loaded with a water cooled jacket. The intrinsic oxygen fugacity of such type of vessel was determined to be close to $1 \log$ unit above the $\mathrm{Ni}-\mathrm{NiO}$ oxygen buffer $(\mathrm{NNO}+1)$ by performing experiments with NiPd mixtures as starting material and the calibration of Taylor et al. (1992) (Rouse 2000). Please see below for more details about the control and determination of $\mathrm{fO}_{2}$ during our experiments. Temperature was calibrated against the melting point of $\mathrm{Au}$ and measured with type $\mathrm{K}$ thermocouples (accuracy of $\pm 5^{\circ} \mathrm{C}$ ). Deionized water was used as the pressure medium. Pressure was measured with Bourdon gauges and has an accuracy of $\pm 10 \mathrm{MPa}$. The experiments were run from 750 to $925^{\circ} \mathrm{C}$, at intervals of $50^{\circ} \mathrm{C}$ or $25^{\circ} \mathrm{C}$, at three pressures $(100,200,250 \mathrm{MPa}$, Table 2).

The glass powder was loaded into $\mathrm{Ag}_{70} \mathrm{Pd}_{30}$ capsules, $2.5 \mathrm{~cm}$ long, $2.2 \mathrm{~mm}$ outside diameter, and $0.1 \mathrm{~mm}$ wall thickness. This capsule material has been shown to minimize Fe loss and at the same time it is permeable to H (e.g., Edgar 1979). Variable amounts of de-ionized water (from 1.3 to $10 \mathrm{wt} \%$ ) were added to the dry powder with waterrock ratios that varied from 0.1 to 0.02 . Capsules were welded with a flame torch and re-weighed to check for water-loss during welding. Capsules with weight differences $>$ $0.0004 \mathrm{~g}$ were not used (this corresponds to about $1 \mathrm{wt} \%$ water loss). Successfully welded capsules were left at $110^{\circ} \mathrm{C}$ for about 10 minutes to ensure water homogenization. Capsules were re-weighted and if weight-differences $>0.0004 \mathrm{~g}$ were found the capsules were discarded. After the experiment capsules were re-weighed and only those without significant weight-differences with the pre-annealing values $(<$ $0.0004 \mathrm{~g}$ ) were taken as successful. Capsules were open with pliers and a squirt of water came out of capsules from water-saturated runs. Bubbles were observed in backscattered SEM images from water-saturated runs. Because we are using water as 
pressurizing media the driving force for water leaking out of the capsules is much smaller than in experimental apparatus that use Ar or other pressure media.

The experiments were performed with the following procedure: (1) We first pressurized the system to half value of the desired final pressure and increased the temperature close to the liquidus $\left(900^{\circ} \mathrm{C}\right.$ to $\left.935^{\circ} \mathrm{C}\right)$ in about half an hour. During this period of temperature increase, pressure also increases due to volume changes and the desired pressure is achieved after 30 minutes and maintained constant (2) Later we decreased the temperature to the final target value at a rate of $25^{\circ} \mathrm{C}$ per hour. These temperature-time ramps had the goal of obtaining large crystals (e.g., Luhr 1990), but were not successful since the experimental crystals were still rather small (e.g., Fig. 2b). The decrease in temperature with time may lead to complex interpretation of experimental results (see also Andújar et al. 2008) but only the lowest temperature runs $\left(775^{\circ} \mathrm{C}-800^{\circ} \mathrm{C}\right.$; runs $\left.2,4,19,22\right)$ contain zoned alkali feldspar. Thus, we believe that the step-wise temperature change procedure followed in this work does not have any other effect in the experimental results. Once at the final temperature, the experiments were left for 168-384 hours (this includes the ramp times).

Oxygen fugacity of the experiments compared to those of natural phonolites

The starting glass was synthesized in air and thus at a high oxygen fugacity, and most $\mathrm{Fe}$ should be $\mathrm{Fe}^{3+}$. However, this will not be the prevailing $\mathrm{fO}_{2}$ during the experiments. Once at run conditions, the $\mathrm{Fe}^{2+} / \mathrm{Fe}^{3+}$ values of the melt will reequilibrate to that imposed by the vessel, which is about $1 \log$ unit above the NNO buffer as noted above. Reequilibration and buffering of the $\mathrm{fO}_{2}$ occurs via $\mathrm{H}$ diffusion through the capsule walls and the $\mathrm{Fe}^{2+}$ and $\mathrm{Fe}^{3+}$ reactions in the melt (Huebner 1971; see also 
below). At the very early stage of the experiment the $\mathrm{fO}_{2}$ might have been between that inherited from melting in air and that of the pressure vessel. However, $\mathrm{H}$ diffusion and oxidation/reduction reactions are rapid processes at high $\mathrm{T}$. The $\mathrm{fO}_{2}$ was probably equilibrated in a few hours to that of the pressure vessel. This quick equilibration is supported by the observation that the experimental results from internally heated pressure vessels equipped with Shaw membrane depend on the $\mathrm{fO}_{2}$ imposed by the $\mathrm{H}_{2}$ pressure, even if the starting material was melted in air (e.g., Costa et al. 2004).

All our experiments were run at these oxidizing conditions because there is not a simple technique that allows for a wide range of $\mathrm{fO}_{2}$ to be explored using CSPV. We could not use the double capsule technique where a buffer assemblage is introduced in addition to the starting material (e.g., Huebner 1971) because buffer assemblages are typically fully reacted in much shorter times than the long experimental runs required in our case. An alternative is to insert a large piece graphite rod inside the vessel, which allows reaching FMQ conditions (e.g., Andújar et al. 2008) but has the disadvantage that the fast quench can not be used with this setting. The experimental $\mathrm{fO}_{2}$ we have used is about 2 orders of magnitude higher than the FMQ conditions that have been determined for some phonolites of Tenerife (e.g., Ablay 1997; Ablay et al. 1998; Neumann et al. 1999; Andújar et al. 2008).

The high $\mathrm{fO}_{2}$ conditions in our experiments lead to very early and ubiquitous magnetite crystallization, even close to the liquidus. This has the effect to modify the melt composition from that of the synthesized initial glass. About two percent of magnetite crystallization produced an increase of about $2 \mathrm{wt} \%$ in $\mathrm{SiO}_{2}$, and depletion of $1 \mathrm{wt} \%$ in $\mathrm{FeO}$, and $0.2 \mathrm{wt} \%$ in $\mathrm{TiO}_{2}$ (Table 1). Because of this early crystallization of magnetite we have used the near liquidus glass composition of run 20 (Table 2) rather 
than the initial synthesised glass as a proxy for the initial melt composition of all experiments.

Water activity and contents of the experimental charges and glass

Water-saturated and -undersaturated conditions were investigated by adding different amounts of water to the capsule. For water-saturated experiments we have assumed that the water concentration in the melt was that of the solubility of phonolites determined by Carroll and Blank (1997). We use the ratio (wt $\% \mathrm{H}_{2} \mathrm{O}$ in the melt)/ (wt $\% \mathrm{H}_{2} \mathrm{O}$ in the melt at saturation) as a proxy for water activity $\left(\mathrm{aH}_{2} \mathrm{O}\right)$. Water-undersaturated runs are probably also fluid-undersaturated and the situation is more complex. The water concentration in the melt typically differs from that introduced into the capsule as it increases with the amount of crystallization. We have estimated the melt $\mathrm{H}_{2} \mathrm{O}$-contents through mass balance calculations using the phase proportions of each run (Table 2; see also Andújar et al. 2008). The difference between the added and melt water contents are largest for low temperature runs $6,12,23$, in some cases $>20 \%$ relative, with a final water activity between 0.7 to 1.0 (Table 2). Such variability in the water content in the melt might be also responsible for the heterogeneous mineral compositions found in some runs as discussed in following sections.

The water contents in the glass obtained in such manner might be not very accurate but as long as the capsules have remained a closed system (which we have ensured by several tests noted above) there should be no major discrepancies (e.g., $<1$ wt $\%$ ) between the water in the capsule and the water in the glass. There are two possible additional sources of water that we have not considered: (1) changes in Fe redox state from the annealing in air of the starting glass to that imposed by the pressure vessel may 
lead to an increase in $\mathrm{H}_{2} \mathrm{O}$ by a reaction of the type: $\mathrm{Fe}^{3+}+\mathrm{O}_{2}+1 / 2 \mathrm{H}_{2} \Rightarrow \mathrm{Fe}^{2+}+\mathrm{OH}^{-}$. Even if we assume the extreme case that all $\mathrm{Fe}^{3+}$ was completely reduced to $\mathrm{Fe}^{2+}$ during the run, the low Fe contents of the phonolite only allow for an additional source of 0.1 wt $\% \mathrm{H}_{2} \mathrm{O}$. (2) reaction of the $\mathrm{H}$ with the atmospheric oxygen trapped during capsule preparation also leads to negligible increases of the water content on the order of 0.01 wt $\%$. We finally note that we could not use the water-by-difference method because the high $\mathrm{Na}$ contents of the glasses required already a calibration of the Na-loss during electron microprobe analyses and make the water-by-difference calculations very unreliable.

\section{Analytical techniques}

Run products were first examined with the optical microscope using transmitted and reflected light and later with the SEM. Phase compositions were determined with an electron microprobe (Cameca SX-50), Serveis Cientifico-Tècnics, Universitat de Barcelona with an accelerating voltage of $20 \mathrm{kV}$. Sample current was $6 \mathrm{nA}$ for glasses, and $10 \mathrm{nA}$ for minerals, and beam size of $10 \mu \mathrm{m}$ for minerals and $20 \mu \mathrm{m}$ for glasses. $\mathrm{Na}$ and $\mathrm{K}$ were analysed first. Counting times for glass analyses were $20 \mathrm{~s}$ for $\mathrm{Na}$ and $10 \mathrm{~s}$ for other elements. For mineral analyses counting times were $10 \mathrm{~s}$ for all elements. Alkali migration in glasses was quantified and corrected using secondary phonolitic glasses with $10 \mathrm{wt} \%, 6 \mathrm{wt} \%$ and $1.5 \mathrm{wt} \%$ of added water.

Phase proportions were obtained by least squares mass balance calculations using the composition of the phases listed in Tables 3-6 and the results are shown in Table 2. The small size of some crystals did not always allow obtaining good stoichiometric electron microprobe analyses (Tables 3-6) and we were not able to analyze a single 
biotite. For calculating the phase proportions we used the composition of the biotite from the pre-caldera El Abrigo phonolite (Andújar et al. 2008). In runs where a mineral was not possible to analyse we used the compositions from runs of similar temperatures for mass balance calculations (Table 2; see also Andújar et al. 2008). Clinopyroxene analyses showed high $\mathrm{K}_{2} \mathrm{O}$ contents $(0.2$ to $0.8 \mathrm{wt} \%)$ indicating glass contamination that have been corrected by subtracting different amounts of glass (Table 5). A total of 1140 electron microprobe analyses were performed of which about $75 \%$ have been finally used and more than three analyses per phase were made when possible.

\section{Attainment of equilibrium}

Chemical equilibrium between minerals and melt is supported by the small compositional variations of the phases in most runs, the homogeneous distribution of the phases within the charges, and the presence of euhedral crystals (Fig. 2b). Our long

run durations (one to two weeks) should have also been enough for attainment of equilibrium based on previous experimental works on similar evolved compositions (e.g., Scaillet and Evans 1999; Dall'Agnol et al. 1999; Berndt et al. 2001; Costa et al. 2004; Pichavant et al. 2007; Andújar et al. 2008). Moreover, the fact that experimental results vary according to changes intensive parameters also indicate that each run equilibrated to a good degree at the imposed conditions.

\section{Experimental results}

Most runs have small euhedral crystals $(<10 \mu \mathrm{m}$ to $100 \mu \mathrm{m}$ in length; Fig.2b) that are homogenously distributed within the charge. Experimental minerals are alkali feldspar 
(anorthoclase/sanidine), biotite, diopside, titanite, magnetite, and apatite as an accessory phase (not reported in Table 2).

Phase relations

The phase stabilities of the Lavas Negras phonolite are displayed in several ways using a series of binary diagrams (Fig. 3a to 3d). Magnetite is the liquidus mineral at all investigated water contents and pressures, crystallizing above $925^{\circ} \mathrm{C}$ (Fig. 3). Magnetite crystallization is closely followed by clinopyroxene and biotite which saturate at temperatures $\geq 880^{\circ} \mathrm{C}$ at all investigated conditions. Titanite and alkali feldspar typically first appear at lower temperatures, but a decrease in water content from about 7 to 2 $\mathrm{wt} \%$ increases the first appearance of feldspar from $825 \pm 25^{\circ} \mathrm{C}$ to $900 \pm 25^{\circ} \mathrm{C}$. The stability of rest of the minerals is not significantly affected by a change in the water content, including biotite which is stable down to about $2 \mathrm{wt} \%$ of water in the melt (Fig. $3 b)$.

Crystallinity and phase proportions

Calculated phase proportions show that the crystal content of the charges increases with decreasing temperature, water content, and pressure (Fig. 3). Alkali feldspar is the most abundant mineral in the runs where it is present, followed by clinopyroxene, and magnetite (commonly $<3 \mathrm{wt} \%$ ). Biotite abundance is similar to clinopyroxene or magnetite, and titanite occurs as trace mineral $(<0.5 \mathrm{wt} \%)$. Comparison of the natural and experimental phenocryst content and mineral assemblage allows a first estimation of the pre-eruptive conditions of the phonolite. The natural mineral assemblage 
(anorthoclase, diopside and magnetite) has been reproduced in runs with water contents between 2.5 to $3.5 \mathrm{wt} \%$, temperatures of $880-920^{\circ} \mathrm{C}$, and pressures between 100 and $200 \mathrm{MPa}$ (Fig. 3d). The phase compositions we describe below are coherent with this set of parameters and provide further constrains.

Mineral compositions

Spinel. Magnetite was present in all runs and has $\mathrm{TiO}_{2}$ contents ranging from 3 to $\sim 11$ wt $\%$, and calculated $\mathrm{Fe}_{2} \mathrm{O}_{3}$ contents vary between 42 and $63 \mathrm{wt} \%$ (Table 3; structural formula after Stormer 1983). Magnetite has Mg-numbers between 2 and 10 [Mgnumber $=$ molar $100 \mathrm{Mg} /\left(\mathrm{Mg}+\mathrm{Fe}_{\mathrm{c}}^{2+}\right) ; \mathrm{Fe}_{\mathrm{c}}^{2+}=$ calculated $\mathrm{Fe}^{2+}$ from stoichiometric constraints of structural formula], and ulvöspinel contents between 4 and 35\%. Mgnumber tends to decrease and the ulvöspinel content tends to increase with decreasing temperature and pressure (Table 3, Fig 4). The Mg-number of the natural magnetite $(\sim 4.6)$ is reproduced at 900 and $925^{\circ} \mathrm{C}$ and only at $100 \mathrm{MPa}$, which is in accord with the temperatures obtained from the mineral assemblage and phase proportions of the phonolite. The natural magnetite has higher calculated $\mathrm{FeO}(\sim 42 \mathrm{wt} \%)$ and lower $\mathrm{Fe}_{2} \mathrm{O}_{3}{ }^{\mathrm{c}}$ content $(\sim 32 \mathrm{wt} \%$; Table 1$)$ than the experimental crystals and may indicate that the phonolite was stored at a lower $\mathrm{fO}_{2}($ e.g., $<\mathrm{NNO}+1)$ than the experiments that we have performed.

Biotite and Titanite. Biotite and titanite were identified optically and using SEM-EDS, but due to the small size was not possible to obtain good stoichiometric analyses. 
Alkali Feldspar. Alkali feldspar is anorthoclase or sanidine (Fig.5; end-members calculated as in Deer et al. 1972) with compositions in the range $\mathrm{Or}_{19-47}, \mathrm{Ab}_{51-73}$, and $\mathrm{An}_{2-12}$ (Table 4). The Or content tends to increase, and $\mathrm{Ab}$ and $\mathrm{An}$ contents tend to decrease with decreasing temperature (Fig. 5; Ab and An content are not shown). This variation resembles the composition of the anorthoclase from the phonolite $\left(\mathrm{Or}_{20-30 \text {, }}\right.$ $\left.\mathrm{Ab}_{60-66}, \mathrm{An}_{8-16}\right)$ that was closely reproduced at $900-925^{\circ} \mathrm{C}, 100-200 \mathrm{MPa}$, and water contents between 2 to $3.5 \mathrm{wt} \%$ (Fig.5).

Clinopyroxene. Experimental clinopyroxenes have end-members composition of $\mathrm{En}_{34-38}$, $\mathrm{Wo}_{44-45}, \mathrm{Fs}_{16-19}$ (after Morimoto 1989) with relatively high calculated $\mathrm{Fe}_{2} \mathrm{O}_{3}$ content (about 7 to 11 wt\%; Table 5; Fig.6). Higher $\mathrm{Fe}_{\mathrm{c}}^{3+}$ content may be related to an increase in $\mathrm{Na}$, for charge balance. The Mg-number of clinopyroxene varies from 70 to 90 . The Mg-number decreases, En and Wo content increase, and Fs content slightly decreases with decreasing temperature. The clinopyroxene from the phonolite is diopside $\left(\mathrm{En}_{36-38}\right.$, $\left.\mathrm{Wo}_{46-50}, \mathrm{Fs}_{14-16}\right)$ with a Mg-number of $\sim 60$. Except for the Wo and $\mathrm{Fe}_{\mathrm{c}}^{2+} / \mathrm{Fe}_{\mathrm{c}}^{3+}$, its composition is experimentally reproduced between $875^{\circ} \mathrm{C}$ and $900^{\circ} \mathrm{C}, 100$ and $200 \mathrm{MPa}$, and water contents of 2 to $4.7 \mathrm{wt} \% \mathrm{H}_{2} \mathrm{O}$. These conditions are in accord with those obtained from the mineral assemblage and the crystal content of the phonolite. The difference in Mg-number between the natural and experimental clinopyroxene at the pre-eruptive temperatures and water content is due to the difference in $\mathrm{Fe}_{\mathrm{c}}^{2+}$ content, being higher in the phonolite $\left(\sim 6.5 \mathrm{wt} \% \mathrm{FeO}^{\mathrm{c}}\right)$ and lower in the experiments ( 1 to 3.4 $\mathrm{wt} \%$ ). This suggests that the natural clinopyroxene may have crystallized at more reducing conditions $\left(\mathrm{fO}_{2}<\mathrm{NNO}+1\right)$ and is consistent with the composition of the experimental and natural magnetite compositions. 
Glass. Experimental glass compositions vary with temperature and water content. They are phonolitic and peralkaline [molar $(\mathrm{Na}+\mathrm{K}) / \mathrm{Al}$ between 1.0-1.1], with $\mathrm{SiO}_{2}$ ranging from 60.5 to $62.4 \mathrm{wt} \%, \mathrm{Na}_{2} \mathrm{O} 8.6$ to $9.6 \mathrm{wt} \%$, and $\mathrm{K}_{2} \mathrm{O} 4.6$ to $5.9 \mathrm{wt} \%$ (recalculated to $100 \%$ anhydrous; Table 6; Fig. 7). For a given pressure and water content in the melt, the $\mathrm{SiO}_{2}$ and $\mathrm{Na}_{2} \mathrm{O}$ content increases until a maximum value and then decreases with decreasing temperature (Fig. 7). The $\mathrm{TiO}_{2}, \mathrm{MgO}, \mathrm{CaO}$ and $\mathrm{FeO} *$ contents of the glass decrease with decreasing temperature, whereas $\mathrm{MnO}$ and $\mathrm{K}_{2} \mathrm{O}$ contents do not change significantly with decreasing temperature. The overall variation of glass composition is not very large which probably reflects that the bulk-rock composition is close to that of a eutectic of the phonolitic system.

The $\mathrm{SiO}_{2}, \mathrm{FeO}^{*}, \mathrm{~K}_{2} \mathrm{O}$, and $\mathrm{MnO}$ content of the natural glass are reproduced within the range of pre-eruptive temperature and water content that we have suggested so far using various observations. Experimental $\mathrm{MgO}$ and $\mathrm{CaO}$ are 0.2 and $0.1 \mathrm{wt} \%$ lower than the contents of the starting material, whereas $\mathrm{Na}_{2} \mathrm{O}$ is reproduced at slightly higher water contents, but between 100 and $200 \mathrm{MPa}$. The small mismatch between the natural and experimental glasses may reflect that the magma was stored at a lower $\mathrm{fO}_{2}$ that we have been able to experimentally investigate, as we have already noted for the magnetite and clinopyroxene compositions.

\section{Discussion and conclusions}

Pre-eruptive conditions of Lavas Negras phonolite

During the last 30 ky Teide and Pico Viejo stratovolcanoes have erupted different types of phonolitic magmas but, their pre-eruptive temperatures, pressures, and volatile 
contents have been poorly constrained. We have reproduced the phenocryst content ( $37 \mathrm{wt} \%$ ), mineral assemblage, and most of the phase compositions of the Lavas Negras phonolite at $900 \pm 20^{\circ} \mathrm{C}$, water contents between 2.5 to $3.5 \mathrm{wt} \%$, and at a pressure of $150 \pm 50 \mathrm{MPa}$. Pressures lower than $100 \mathrm{MPa}$ would intercept the biotite field (which is lacking in the phonolite; Fig. 3) at the phenocryst content of the lava. Although phase stability relations cannot rule out pressures higher than $200 \mathrm{MPa}$, the $\mathrm{Al}_{2} \mathrm{O}_{3}$ content of clinopyroxene crystallized at $900^{\circ} \mathrm{C}, 200 \mathrm{MPa}$ is about $4 \mathrm{wt} \%$ which is higher than those of the phonolite $(1.6 \mathrm{wt} \%)$ and suggests pressures $<200 \mathrm{MPa}$ (e.g., Putirka et al. 2003).The range of pre-eruptive pressures that we propose are within the previously $200 \pm 100 \mathrm{MPa}$ obtained from natural clinopyroxenes by Ablay et al. (1998). The pre-eruptive $\mathrm{fO}_{2}$ is more difficult to constrain because all our experiments were run at a single oxygen buffer $(\mathrm{NNO}+1)$. The $\mathrm{Mg}$-number of the natural magnetite is experimentally reproduced but it has higher $\mathrm{Fe}_{\mathrm{c}}^{2+} / \mathrm{Fe}_{\mathrm{c}}^{3+}$. The low Mg-number and the higher $\mathrm{Fe}_{\mathrm{c}}^{2+}$ content of the natural clinopyroxene is not reproduced experimentally. This would suggest crystallization under more reduced conditions than the studied in this work. Andújar et al. (2008) showed that the $\mathrm{FeO}^{\mathrm{c}} / \mathrm{Fe}_{2} \mathrm{O}_{3}{ }^{\mathrm{c}}$ values of magnetite and clinopyroxene are a good proxy of $\mathrm{fO}_{2}$ in phonolitic compositions. Comparison of the $\mathrm{Fe}_{\mathrm{c}}^{3+} /\left(\mathrm{Fe}_{\mathrm{c}}^{2+}+\mathrm{Fe}_{\mathrm{c}}^{3+}\right)$ content of the natural and experimentally produced magnetite and clinopyroxene shows that both minerals are better reproduced close to FMQ conditions rather than at $\mathrm{NNO}+1$. We suggest that the Lavas Negras magma was probably stored close to FMQ. These $\mathrm{fO}_{2}$ conditions are also in accord with older phonolites erupted from Teide-Pico Viejo complex and obtained from natural ilmenite and magnetite pairs. Decreasing the $\mathrm{fO}_{2}$ from NNO+1 to FMQ in our experiments would have minor effects in mineral stability but it would affect to the ferro-magnesian mineral composition as can be seen from other experimental works. However, bitotite and clinopyroxene would 
change their composition to higher $\mathrm{Fe}_{\mathrm{c}}^{2+} / \mathrm{Fe}_{\mathrm{c}}^{3+}$ ratios achieving values close to those of the natural phonolite (e.g., Berndt et al. 2001; Freise et al. 2003; Andújar et al. 2008).

Implications for understanding the magma plumbing system of Teide

The new experimental data that we report allow us to infer the present state of the Teide shallow magma system. If we assume that during the last $\sim 1000$ years no major structural changes have affected the island of Tenerife, any magma residual from the Lavas Negras eruption should be still located at $\sim 5 \mathrm{~km}$ depth from the current summit of Teide. Depending on the volume of the remaining magma, the reservoir shape, and the fluid dynamics of the magma and possible hydrothermal system, the temperature and crystallinity have probably changed. Our results suggest that left over magma should be stored at $\leq 900^{\circ} \mathrm{C}$ and with $\geq 30-40 \mathrm{wt} \%$ of phenocrysts if no new input of magma has occurred.

The depths, thermal state, and rheology of the magma reservoir that we propose should be helpful for understanding new geophysical studies and future volcano monitoring data of Teide volcano. For example, knowledge of the depth of the reservoir allows interpretation of the source of deformation and seismic data. The temperature, pressure, crystallinity, and volatile content of the magma is also important for understanding the gas composition and speciation measured at the surface, and for the application of geophysical techniques aimed at understanding the magmatic plumbing system of Teide.

\section{Acknowledgements}


Reviews by D. Johnson and anonymous helped to clarify many aspects of the manuscript, in particular the experimental strategy. The careful editorial handling and suggestions of M. Clynne improved various versions of the manuscript and are appreciated. This work has been mainly funded by European and Spanish research grants (ERUPT and TECTOTENE projects). J. Andújar and F. Costa acknowledge fellowships from the "Beatriu de Pinós" and "Ramon y Cajal" programs, respectively.

\section{References}

Abdel-Monem A, Watkins ND, Gast PW (1972) Potassium-Argon ages, volcanic stratigraphy and geomagnetic polarity history of the Canary Islands: Tenerife, La Palma and Hierro. Amer J Sci 272:805-825

Ablay GJ (1997) Evolution of the Teide-Pico Viejo volcanic complex and magmatic system (Tenerife, Canary Islands). PhD. Thesis. Department of Geology. Bristol, University of Bristol.

Ablay GJ, Ernst GGJ, Martí J, Sparks RSJ (1995) The 2 ka subplinian eruption of Montaña Blanca, Tenerife. Bull Volcanol 57:337-355

Ablay GJ, Carroll MR, Palmer MR, Martí J, Sparks RSJ (1998) Basanite-Phonolite Lineages of the Teide-Pico Viejo Volcanic Complex, Tenerife, Canary Islands. J Petrol 39:905-936

Ablay GJ, Martí J (2000) Stratigraphy, structure, and volcanic evolution of the Pico Teide-Pico Viejo formation, Tenerife, Canary Islands. J Volcanol Geotherm Res $103: 175-208$

Ancochea E, Fúster JM, Ibarrola E, Cendrero A, Coello J, Hernán F, Cantagrel JM, Jamond C (1990) Volcanic evolution of the island of Tenerife (Canary Islands) in the light of new K-Ar data. J Volcanol Geotherm Res 44:231-249 
Andújar J, Costa F, Martí J, Wolff JA, Caroll MR (2008) Experimental constraints on pre-eruptive conditions of phonolitic magma from the caldera-forming El Abrigo eruption, Tenerife (Canary islands). Chem Geol 257:173-191

Araña V. (1971). Litología y estructura del Edificio Cañadas, Tenerife (Islas Canarias). Estudios Geologicos 27:95-135

Berndt J, Holtz F, Koepke J (2001) Experimental constraints on storage conditions in the chemically zoned phonolitic magma chamber of the Laacher See volcano. Contrib Mineral Petrol 140:469-486

Carracedo JC, Rodríguez-Badiola E, Guillou H, Paterne M, Scaillet S, Pérez-Torrado FJ, Paris R, Fra-Paelo U, Hansen A (2007) Eruptive and structural history of Teide volcano and rift zones of Tenerife, Canary Islands. Geol Soc Am Bull 119:10271051

Carroll MR, Blank JG (1997) The solubility of $\mathrm{H}_{2} \mathrm{O}$ in phonolitic melts. Am Mineral $82: 549-556$

Costa F, Scaillet B, Pichavant M (2004) Petrological and experimental constraints on the Pre-eruption conditions of Holocene dacite from Volcán San Pedro $\left(36^{\circ} \mathrm{S}\right.$, Chilean Andes) and the im portance of sulphur in silicic subduction-related magmas. J Petrol 45: 855-881

Dall'Agnol RS, Scaillet B, Pichavant M (1999) An experimental study of a lower Proterozoic A-type granite from the eastern Amazonia craton, Brazil. J Petrol 40:1673-1697

Deer WA, Howie RA, Zussman J (1972) Rock forming minerals: Framework silicates 4. Longman, London

Edgar AD (1979) Experimental petrology: Basic principles and techniques. Claredon Press 
Freise M, Holtz F, Koepke J, Scoates J, Leyrith H (2003) Experimental constraints on the storage conditions of phonolites from Kerguelen Archipelago. Contrib Mineral Petrol 145:659-672

Fúster JM, Araña V, Brandle JL, Navarro JM, Alonso U, Aparicio A (1968) Geology and volcanology of the Canary Islands: Tenerife. Instituto Lucas Mallada, CSIC, Madrid, $218 \mathrm{pp}$

Grove TL, Kinzler RJ, Bartels KS (1989) Effects of pressure on alumina substitution in igneous augite: An empirical geobarometer. EOS Transac AGU 70, 1401-1402

Hausen H (1956) Contributions to the geology of Tenerife. Soc Sci Fenn Comm Phys Math 18:1-247

Huebner JS (1971) Buffering techniques for hydrostatic systems at elevated pressures. In Ulmer, GC Research Techniques for high pressure and high temperature. Springer Verlag

Huebner JS, Sato M (1970) The oxygen fugacity-temperature relationships of manganese and nickel oxide buffers. Am Mineral 55:934-952

Johannes W, Bode B (1978) Loss of iron to the Pt-container in melting experiments with basalts and a method to reduce it. Contrib Mineral Petrol 67:221-225.

Luhr JF (1990) Experimental phase relations of water-and sulfur-saturated arc magmas and the 1982 eruptions of El Chichon volcano. J Petrol 31:1071-1114

Martí J, Mitjavila J, Araña V (1994) Stratigraphy, structure and geochronology of the Las Cañadas caldera (Tenerife, Canary Island). Geol Mag 131:715-727

Martí J, Hurlimann M, Ablay GJ, Gudmundsson A (1997) Vertical and lateral collapses on Tenerife (Canary Islands) and other volcanic ocean islands. Geology 25:879-882 
Martí J, Gudmundsson A (2000) The Las Cañadas caldera (Tenerife, Canary Islands): an overlapping collapse caldera generated by magma-chamber migration. J Volcanol Geotherm Res 103:161-173

Martí J, Geyer A, Andújar J, Teixidó F, Costa F (2008) Assessing the potential for future explosive activity from Teide-Pico Viejo. J Volcanol Geotherm Res 178:529542

Martí J, Ortiz R, Gottsmann J, García A, De La Cruz-Reina S (2009) Characterising unrest during the reawakening of the central volcanic complex on Tenerife, Canary Islands, 2004-2005, and implications for assessing hazards and risk mitigation. J Volcanol Geotherm Res 182:23-33

Morimoto N (1989) Nomenclature of pyroxenes. Subcommittee on pyroxenes. Commission on new minerals and mineral names. Can Mineral 27:143-156

Neumann E-R, Wulff-Pedersen E, Simonsen SL, Pearson NJ, Martí J, Mitjavila J (1999) Evidence for fractional crystallization of periodically refilled magma chambers in Tenerife, Canary Islands. J Petrol 40:1089-1123

Pichavant M, Costa F, Burgisser A, Scaillet B, Martel C, Poussineau S (2007) Equilibration scales in silicic to intermediate magmas - Implications for phase equilibrium studies. J Petrol 48:1955-1972

Putirka K, Ryerson FJ, Mikaelian H (2003) New igneous thermobarometers for mafic and evolved lava compositions based on clinopyroxene + liquid equilibria, Am Mineral 88:1542-1554

Rouse P (2000) Experimental phase equilibria of sodic phonolites from Montaña Blanca, Tenerife. PhD. Thesis. University of Bristol, Bristol

Scaillet B, Evans BW (1999) The 15 June 1991 eruption of Mount Pinatubo. I. phase equilibria and Pre-eruption P-T- $f \mathrm{O}_{2}-\mathrm{aH}_{2} \mathrm{O}$. J Petrol 40:381-411 
Stormer JC (1983) The effects of recalculation on estimates of temperature and oxygen fugacity from analyses of multicomponent iron-titanium oxides. Am Mineral 68: 586-594

Taylor JR, Wall VJ, Pownceby MI (1992) The calibration and application of accurate redox sensors. Am Mineral 77:284-295

Thirlwall MF, Singer BS, Marriner GF (2000) ${ }^{39} \mathrm{Ar} /{ }^{40} \mathrm{Ar}$ ages and geochemistry of the basaltic shield stage of Tenerife, Canary Islands, Spain. J Volcanol Geotherm Res 103: $247-297$

\section{Figure Captions}



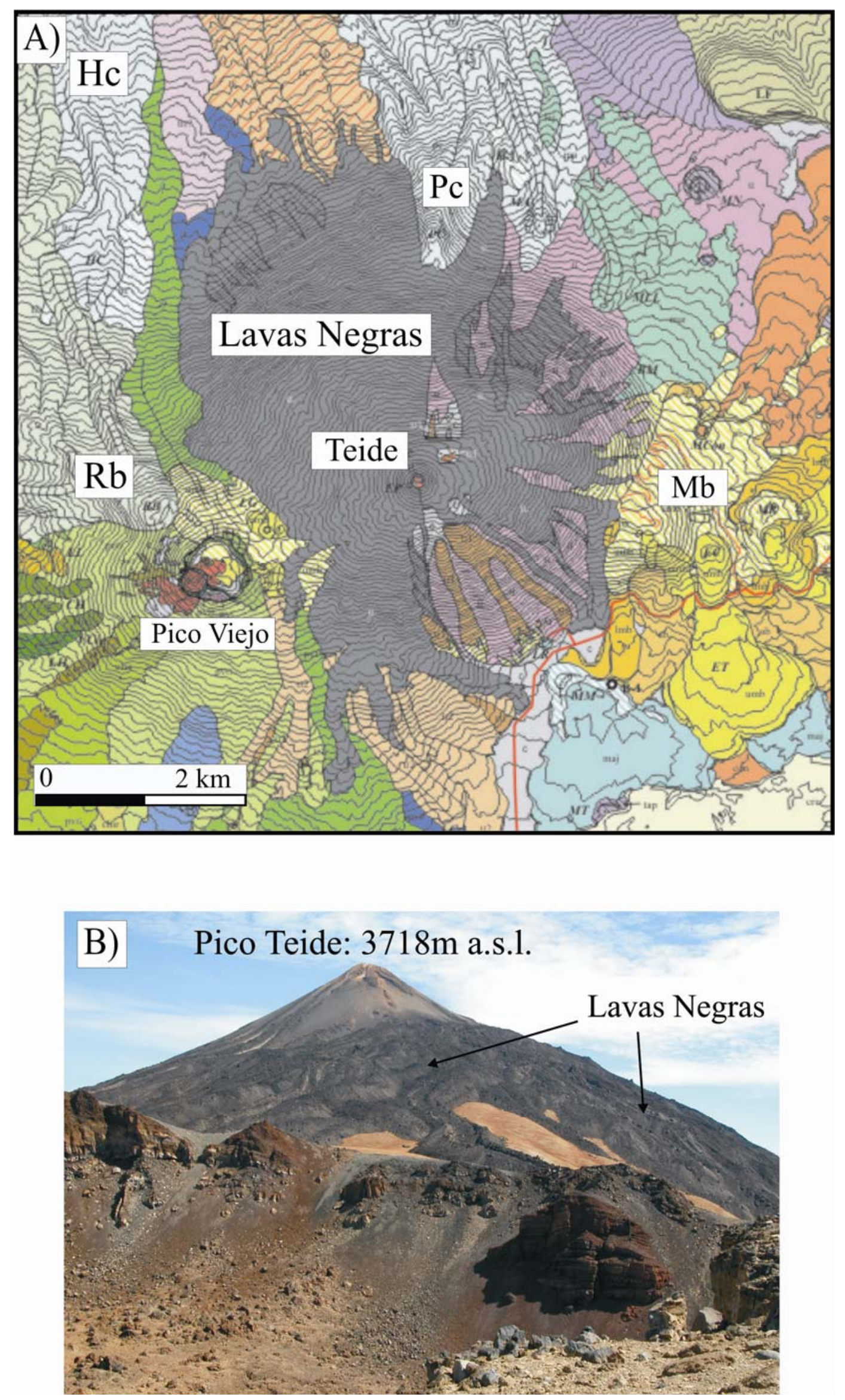
Figure 1. A) Detail of simplified geological map of the Teide-Pico Viejo stratovolcanoes with the units following Ablay and Martí (2000). The Lavas Negras is the last phonolitic eruption of Teide and covers most of its flanks. The main phonolitic units are also labelled as the following, Rb: Roques Blancos, Hc: Hoya del Cedro, Pc: Pico Cabras, Mb: Montaña Blanca. B) View of Pico Teide looking to the North-East with the dark Lavas Negras flows. Part of the crater of Pico Viejo is also seen in the forefront.
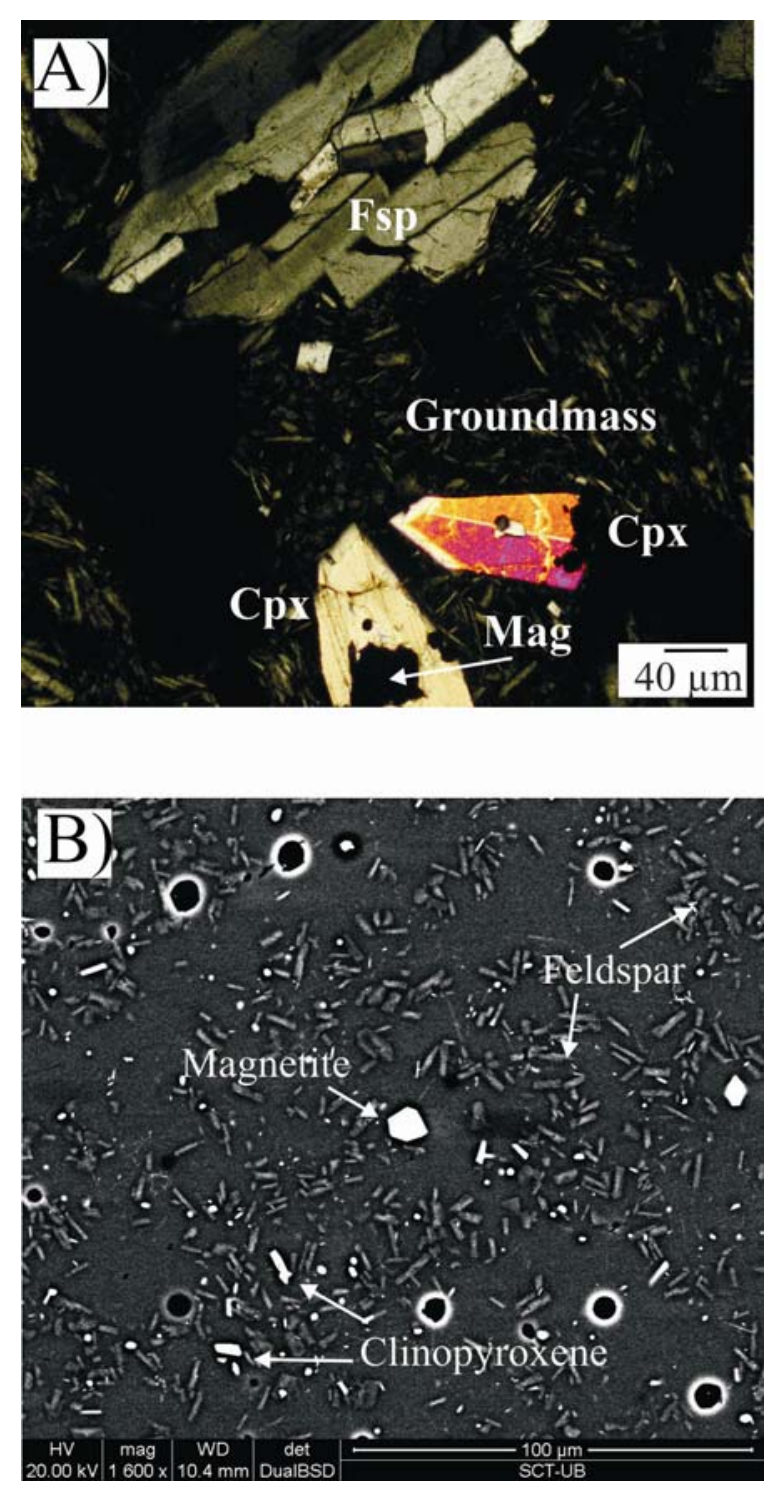

Figure 2. A) Photomicrograph (crossed-polars) of the Lavas Negras phonolite (Fsp: feldspar, Cpx: Clinopyroxene, Mag: Magnetite), B) Backscattered SEM image of experimental charge that contains about $75 \mathrm{wt} \%$ of glass, and crystals of magnetite, 
clinopyroxene, and feldspar. Note that the crystals are small but euhedral and unzoned. The circles with bright borders are dirt particles not bubbles.
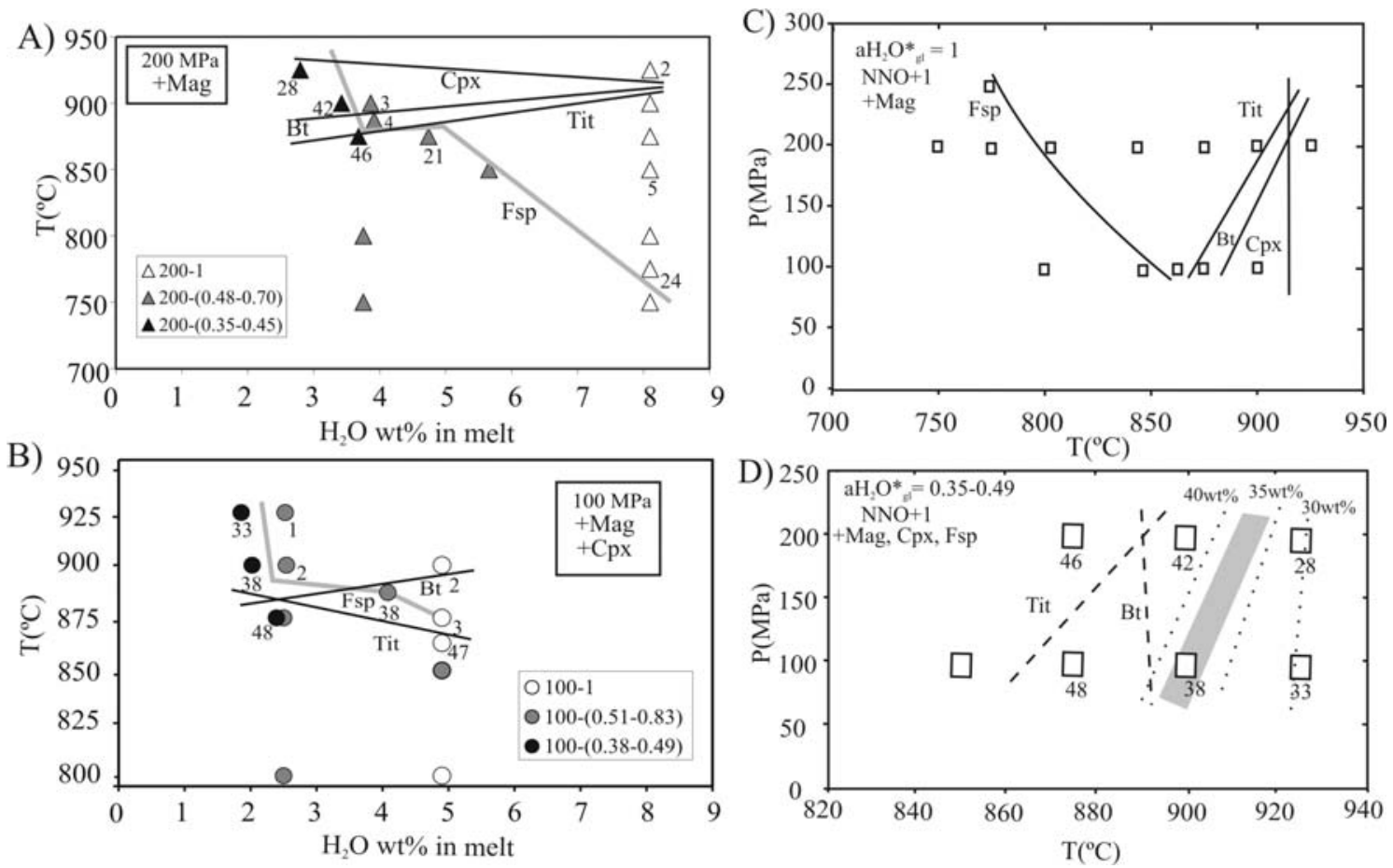

Figure 3. a) Phase relations of the Lavas Negras phonolite at $200 \mathrm{MPa}$ and $\mathrm{NNO}+1$; b) Phase relations of the Lavas Negras phonolite at $100 \mathrm{MPa}$ and $\mathrm{NNO}+1$; c) Phase relations at water-saturated conditions $\left(\mathrm{aH}_{2} \mathrm{O}_{\mathrm{gl}}=1\right)$ at various $\mathrm{P}$ and $\mathrm{T}$; d) Phase relations at water-undersaturated conditions $\left(\mathrm{aH}_{2} \mathrm{O}_{\mathrm{gg}}=0.35-0.50\right)$ at various $\mathrm{P}$ and $\mathrm{T}$. Mag: magnetite; Bt: biotite; Tit: titanite; Cpx: clinopyroxene; Fsp: alkali feldspar. Numbers next to the symbols in plates (a), (b), (d) indicate the wt \% crystals content of the experimental charges (see Table 3). Dashed lines are estimated phase boundaries. Dotted lines are contours of crystal content. Grey band in plate (d) shows the ranges of phenocryst content of Lavas Negras rock. Numbers next to the symbols in the legends of (a) and (b) correspond to pressure and estimated water activity $\left(\mathrm{aH}_{2} \mathrm{O}_{\mathrm{gl}}\right)$. Grey line in plates (a) and (b) define feldspar stability field. 

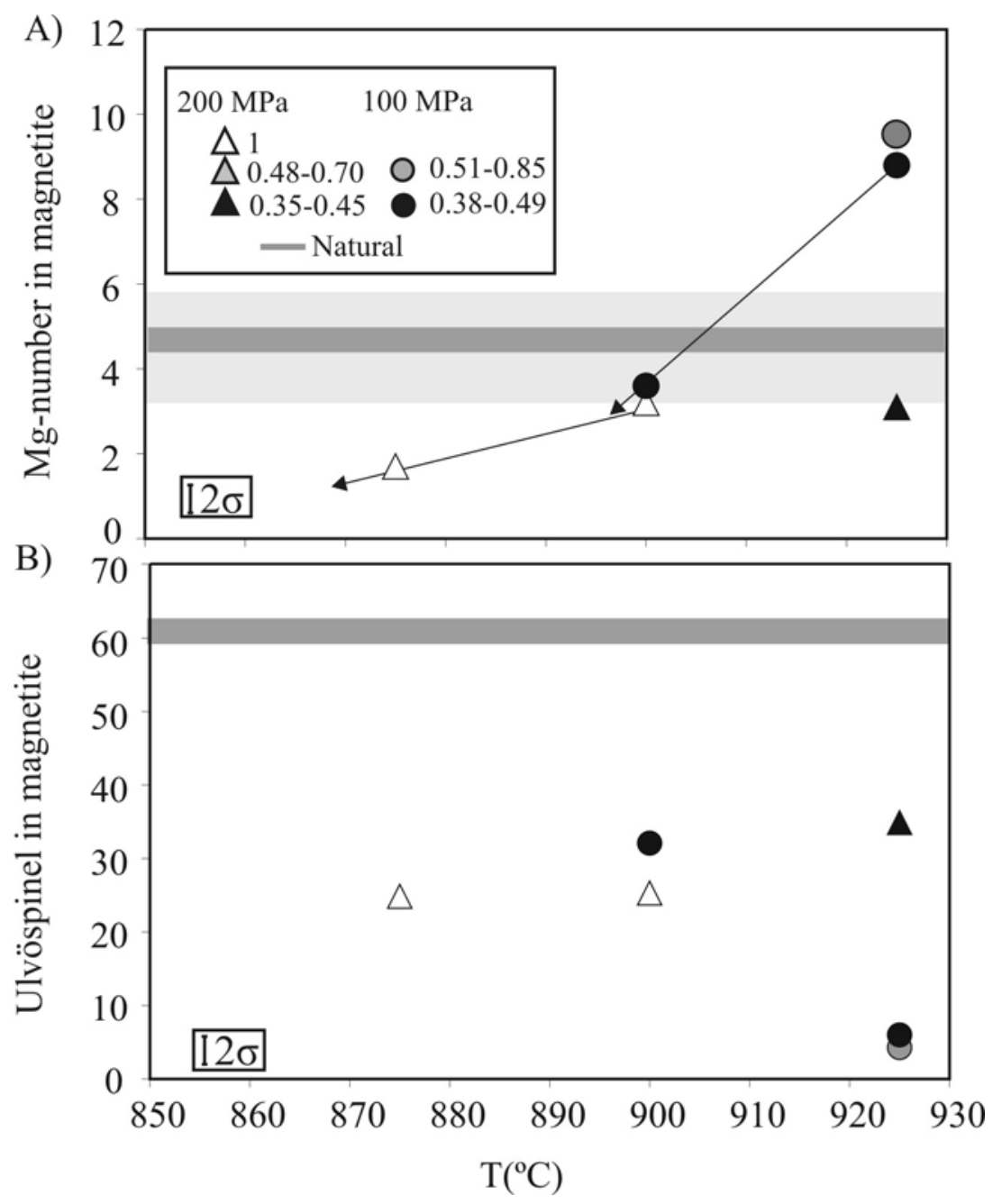

Figure 4. Compositional variation of magnetite (A, Mg-number; B ulvöspinel content) with temperature. Horizontal grey bar shows the natural composition and the associated error. Numbers next to the symbols in the legend correspond to water activity. Arrows show tendencies of compositional changes with decreasing temperature. 
A)
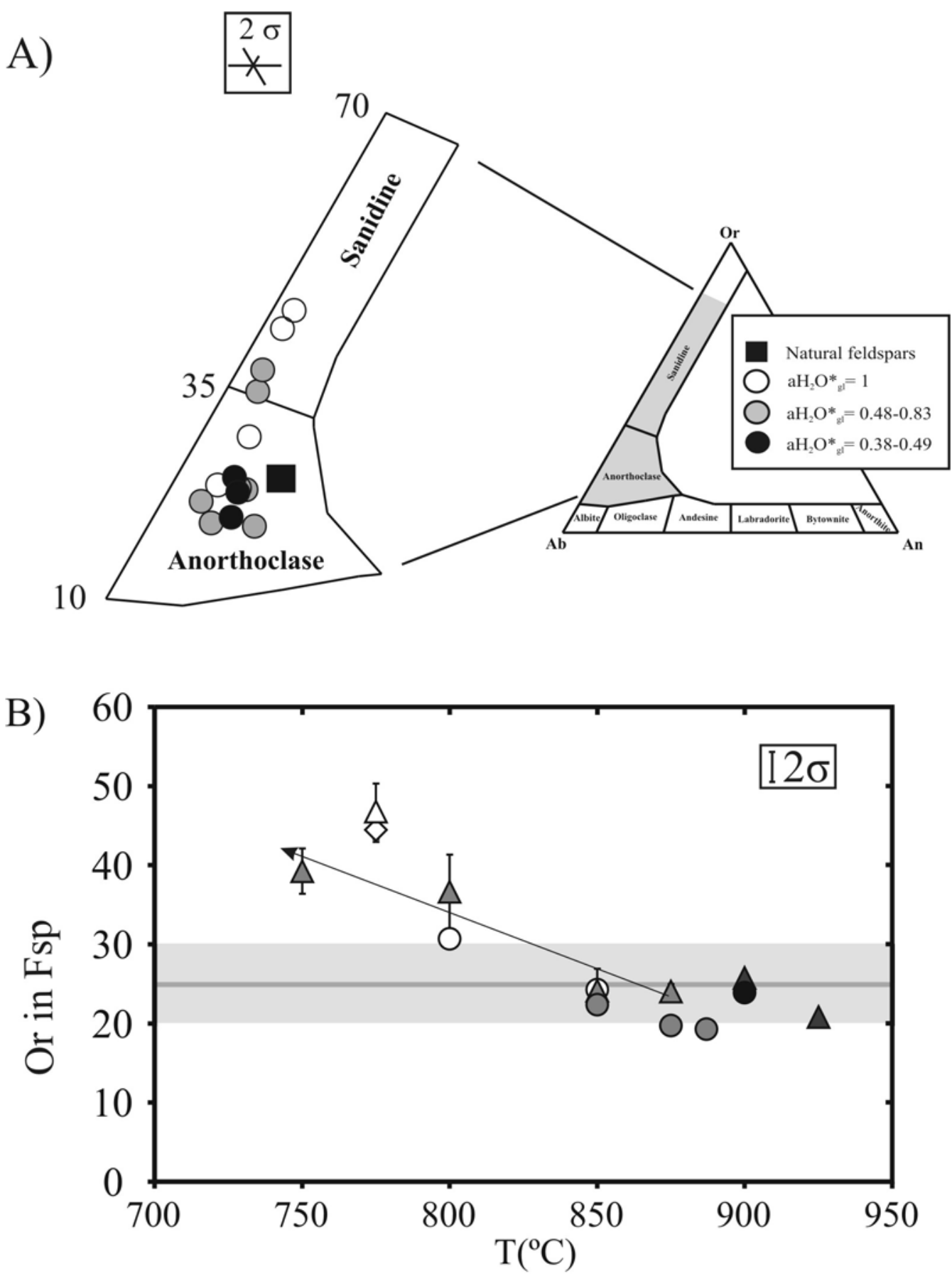

\begin{tabular}{|c|c|}
\hline & \\
\hline & ○ 100-(0.51-0.83) \\
\hline & \\
\hline
\end{tabular}

Figure 5. Classification and compositional variation of feldspar with temperature. a) Natural and experimental feldspar classification (after Deer et al. 1972). b) Variation of the Or content of natural and experimental alkali feldspar with temperature. Horizontal grey bar shows the natural composition (Nat) and the associated error. Numbers next to 
symbols in the legend indicate pressure and water activity. Arrow highlights the increasing Or content with decreasing temperature.
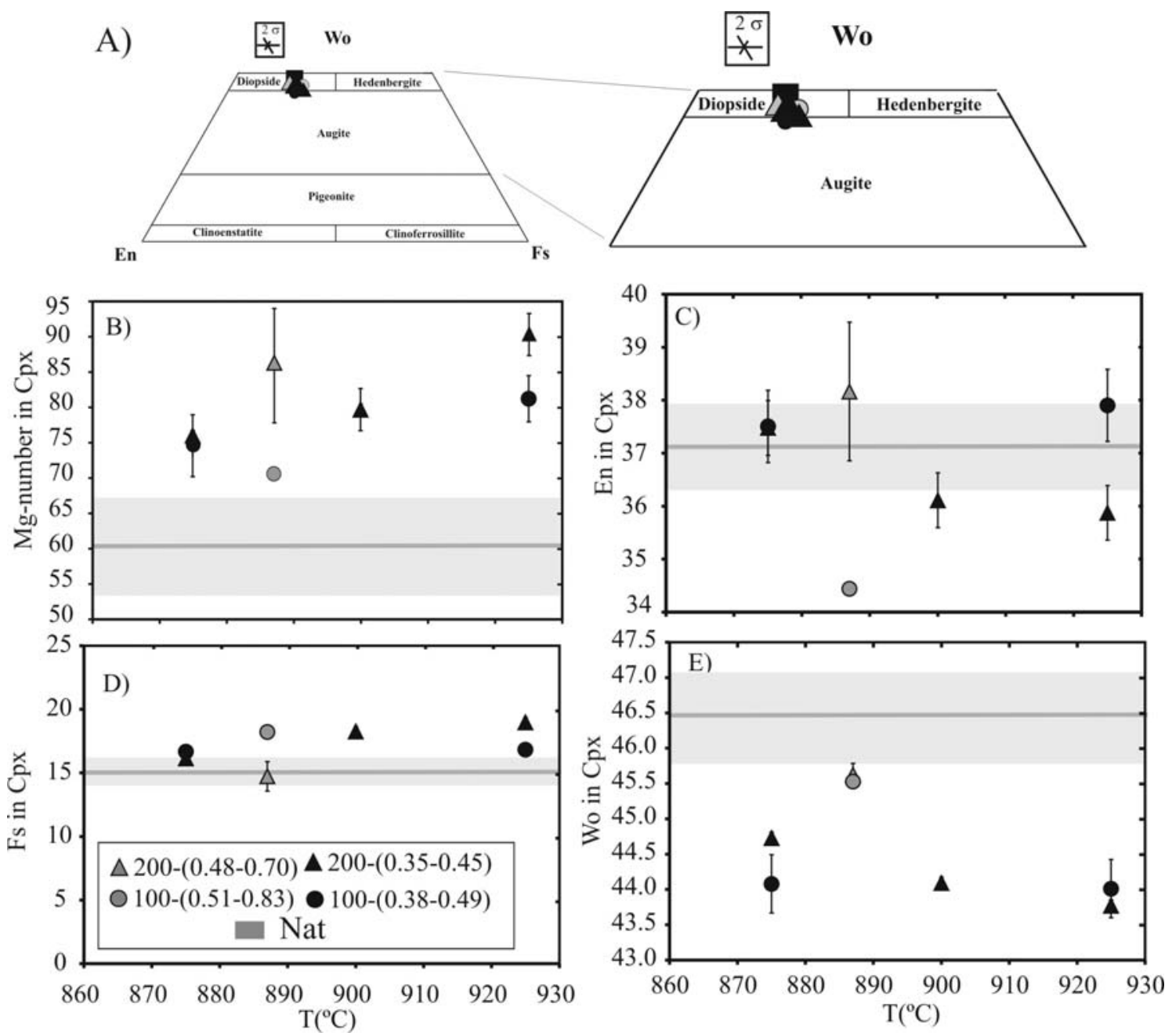

Figure 6. Classification and compositional variation of clinopyroxene with temperature.

A) Classification of natural and experimental clinopyroxenes (after Morimoto, 1989); b)

Variation of the Mg-number c) enstatite (En) content; d) ferrosilite (Fs) content; e) wollastonite (Wo) content of natural and experimental clinopyroxenes with temperature. Horizontal grey bar shows the natural composition (Nat) and the associated error. Numbers attached to symbols indicate pressure and water activity. Numbers next to symbols in the legend indicate pressure and water activity. 

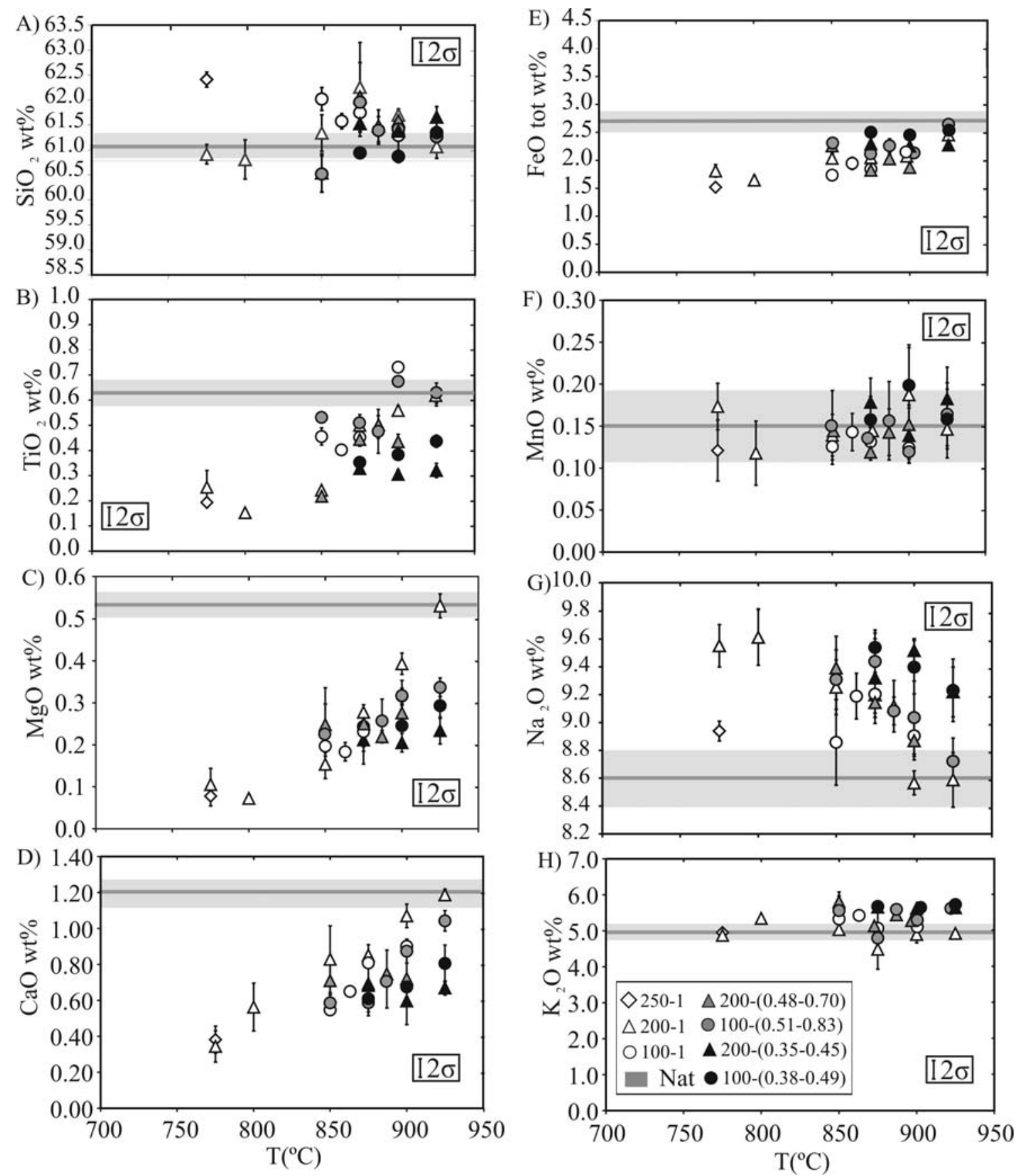

Figure 7. Glass compositional variation of major and minor oxides with temperature (A to $\mathrm{H}$ ). Horizontal grey bar shows natural glass composition and associated error. Numbers next to symbols in the legend indicate pressure and water activity. See text for details about the match of experimental and natural glasses at the pre-eruptive conditions. 
Table 1: Major element compositions (in wt\%) of bulk-rock, glass, and minerals of the natural sample, and starting material.

\begin{tabular}{|c|c|c|c|c|c|c|c|c|c|c|}
\hline & bulk-rock & $\begin{array}{c}\text { starting } \\
\text { material }\end{array}$ & sd & $\begin{array}{c}\text { near } \\
\text { liquidus } \\
\text { glass }^{1}\end{array}$ & magnetite & sd & anorthoclase & sd & diopside & sd \\
\hline $\mathrm{n}$ & & 5 & & 9 & 2 & & 21 & & 10 & \\
\hline $\mathrm{SiO}_{2}$ & 60,1 & 59,4 & 0,5 & 61,1 & 0,64 & 0,67 & 65,0 & 0,8 & 51,3 & 0,7 \\
\hline $\mathrm{TiO}_{2}$ & 0,78 & 0,81 & 0,05 & 0,63 & 17,46 & 0,33 & 0,14 & 0,10 & 0,95 & 0,43 \\
\hline $\mathrm{Al}_{2} \mathrm{O}_{3}$ & 18,77 & 19,25 & 0,34 & 20,24 & 1,51 & 0,21 & 19,93 & 0,58 & 1,56 & 0,60 \\
\hline $\mathrm{MgO}$ & 0,55 & 0,52 & 0,02 & 0,54 & 2,50 & 0,30 & 0,01 & 0,01 & 12,32 & 0,48 \\
\hline $\mathrm{CaO}$ & 1,25 & 1,20 & 0,04 & 1,21 & 2,13 & 0,00 & 1,34 & 0,52 & 21,44 & 0,78 \\
\hline $\mathrm{MnO}$ & 0,18 & 0,16 & 0,05 & 0,15 & 0,05 & 0,01 & - & - & 0,79 & 0,08 \\
\hline $\mathrm{FeO}^{*}$ & 3,90 & 3,90 & 0,23 & 2,56 & 71,1 & 0,9 & 0,40 & 0,18 & 8,92 & 0,53 \\
\hline $\mathrm{Na}_{2} \mathrm{O}$ & 9,20 & 9,18 & 0,20 & 8,59 & - & - & 7,87 & 0,56 & 1,19 & 0,27 \\
\hline $\mathrm{K}_{2} \mathrm{O}$ & 5,17 & 5,20 & 0,18 & 5,02 & - & - & 4,66 & 0,82 & 0,00 & 0,00 \\
\hline $\mathrm{P}_{2} \mathrm{O}_{5}$ & 0,14 & - & - & - & - & - & - & - & - & - \\
\hline $\mathrm{Cl}$ & - & 0,34 & - & - & - & - & - & - & - & - \\
\hline Total & 100,0 & 100,0 & - & 100,0 & 98,6 & - & 99,3 & 0,3 & 98,9 & - \\
\hline Original Sum & 99,3 & 100,7 & - & 93,1 & 95,4 & 0,7 & - & - & 98,4 & 0,6 \\
\hline $\mathrm{Fe}_{2} \mathrm{O}_{3}{ }^{\mathrm{c}}$ & - & - & - & - & 42,0 & - & - & - & 2,90 & 0,60 \\
\hline $\mathrm{FeO}^{\mathrm{c}}$ & - & - & - & - & 32,3 & - & - & - & 6,50 & 0,60 \\
\hline a.p.f.u. & & & & & & & & & & \\
\hline $\mathrm{Fe}^{2+}{ }_{\mathrm{c}}$ & - & - & - & - & 1,28 & 0,03 & - & - & 0,20 & 0,02 \\
\hline $\mathrm{Fe}^{3+}{ }_{\mathrm{c}}$ & - & - & - & - & 0,92 & 0,05 & - & - & 0,08 & 0,02 \\
\hline $\mathrm{Fe}^{3+}{ }_{c} /\left(\mathrm{Fe}^{2+}{ }_{\mathrm{c}}+\mathrm{Fe}^{3+}{ }_{c}\right)$ & - & - & - & - & 0,42 & - & - & - & 0,29 & - \\
\hline
\end{tabular}




Mg-number
Or




\begin{tabular}{|c|c|c|c|c|c|c|c|c|c|}
\hline Experiment & $\begin{array}{l}\text { duration } \\
\text { (hours) }\end{array}$ & $\mathrm{P}(\mathrm{MPa})$ & $\mathrm{T}\left({ }^{\circ} \mathrm{C}\right)$ & $\log f \mathrm{O}_{2}{ }^{\mathrm{a}}$ (bar) & $\begin{array}{c}\mathrm{wt} \% \mathrm{H}_{2} \mathrm{O} \\
\text { added }^{\mathrm{b}}\end{array}$ & $\mathrm{aH}_{2} \mathrm{O}^{*}{ }_{\text {in }}{ }^{\mathrm{c}}$ & $\begin{array}{c}\mathrm{wt} \% \mathrm{H}_{2} \mathrm{O} \\
\text { glass }{ }^{\mathrm{d}}\end{array}$ & $\mathrm{aH}_{2} \mathrm{O}_{\mathrm{gl}}{ }^{\mathrm{e}}$ & wt $\%$ phases $^{f}$ \\
\hline LN 22 & 248 & 250 & 775 & $-13,32$ & 10,0 & 1,0 & 9,5 & 1,00 & Gl(91),Fsp(4),Mag(1),Bt(1),Cpx(3),Tit(1) \\
\hline LN 20 & 214 & 200 & 925 & $-10,37$ & 8,0 & 1,0 & 8,1 & 1,00 & Gl(98),Mag(2) \\
\hline LN 15 & 196 & 200 & 900 & $-10,82$ & 8,0 & 1,0 & 8,1 & 1,00 & Gl(99),Mag(trace),, Сpx(trace),Bt(1),Tit(trace) \\
\hline LN 7 & 197 & 200 & 875 & $-11,28$ & 8,0 & 1,0 & 8,1 & 1,00 & Gl(93),Mag(1),Cpx(1),Bt(5),Tit (trace) \\
\hline LN 5 & 196 & 200 & 850 & $-11,76$ & 8,0 & 1,0 & 8,1 & 1,00 & Gl(95),Mag,Cpx(1),Bt(3),Tit(1) \\
\hline LN 1 & 312 & 200 & 800 & $-12,79$ & 8,0 & 1,0 & 8,1 & 1,00 & Gl(95),Mag(1),Cpx(3),Bt(trace),Tit(1) \\
\hline LN 19 & 384 & 200 & 775 & $-13,34$ & 8,0 & 1,0 & 8,1 & 1,00 & Gl(76),Fsp(11),Mag(2),Bt(3),Cpx(6),Tit(2) \\
\hline LN $3^{\text {h }}$ & 288 & 200 & 750 & $-13,92$ & 8,0 & 1,0 & 8,1 & 1,00 & Gl,Fsp,Mag,Bt,Cpx,Tit \\
\hline LN 17 & 168 & 100 & 900 & $-10,85$ & 5,8 & 1,0 & 4,9 & 1,00 & Gl(99),Mag(trace),Сpx(1) \\
\hline LN 13 & 245 & 100 & 875 & $-11,32$ & 5,8 & 1,0 & 4,9 & 1,00 & Gl(97),Mag(trace),Cpx(1),Bt(1) \\
\hline LN 24 & 224 & 100 & 863 & $-11,55$ & 6,0 & 1,0 & 4,9 & 1,00 & Gl(95),Mag(1),Cpx(2),Bt(1),Tit(trace) \\
\hline LN 11 & 246 & 100 & 850 & $-11,80$ & 5,8 & 1,0 & 4,9 & 1,00 & Gl(50),Fsp(40),Mag(2),Bt(3),Cpx(2),Tit(3) \\
\hline LN $9^{\text {h }}$ & 246 & 100 & 800 & $-12,83$ & 5,8 & 1,0 & 4,9 & 1,00 & Gl,Fsp,Mag,Bt,Cpx,Tit \\
\hline LN 16 & 196 & 200 & 900 & $-10,82$ & 3,8 & 0,5 & 3,9 & 0,48 & Gl(97),Mag(1),Cpx(2) \\
\hline LN 21 & 214 & 200 & 887 & $-11,05$ & 3,8 & 0,5 & 3,9 & 0,48 & Gl(97),Mag(1),Cpx(2),Bt(1) \\
\hline LN 8 & 197 & 200 & 875 & $-11,28$ & 3,8 & 0,5 & 4,7 & 0,59 & Gl(78),Fsp(18),Mag(1),Bt(2),Cpx(trace) \\
\hline LN $6^{\text {g }}$ & 196 & 200 & 850 & $-11,76$ & 3,8 & 0,5 & 5,7 & 0,70 & Gl(67),Fsp(28),Mag(2),Bt(1),Cpx(1),Tit(1) \\
\hline $\mathrm{LN} 2^{\mathrm{h}}$ & 312 & 200 & 800 & $-12,79$ & 3,8 & 0,5 & 3,8 & 0,46 & Gl,Fsp,Mag,Bt,Cpx,Tit \\
\hline $\mathrm{LN} 4^{\mathrm{h}}$ & 288 & 200 & 750 & $-13,92$ & 3,8 & 0,5 & 3,8 & 0,46 & Gl,Fsp,Mag,Bt,Cpx,Tit \\
\hline LN 26 & 201 & 100 & 925 & $-10,41$ & 2,5 & 0,5 & 2,5 & 0,52 & Gl(99),Mag(trace),Сpx(1) \\
\hline LN 18 & 168 & 100 & 900 & $-10,85$ & 2,5 & 0,5 & 2,5 & 0,52 & Gl(98),Mag(trace),Сpx(1) \\
\hline $\mathrm{LN} 23^{\mathrm{g}}$ & 216 & 100 & 887 & $-11,09$ & 2,5 & 0,5 & 4,1 & 0,83 & Gl(61),Fsp(34),Mag(trace),Bt(3),Cpx(2) \\
\hline LN $14^{\mathrm{h}}$ & 245 & 100 & 875 & $-11,32$ & 2,5 & 0,5 & 2,5 & 0,51 & Gl,Fsp,Mag,Bt,Cpx \\
\hline $\mathrm{LN} 12^{\mathrm{g}}$ & 246 & 100 & 850 & $-11,80$ & 2,5 & 0,5 & 4,9 & 1,00 & Gl(47),Fsp(47),Mag(1),Bt(3),Cpx(2),Tit(trace) \\
\hline LN $10^{\mathrm{h}}$ & 269 & 100 & 800 & $-12,83$ & 2,5 & 0,5 & 2,5 & 0,51 & Gl,Fsp,Mag,Bt,Cpx,Tit \\
\hline LN 31 & 195 & 200 & 925 & $-10,37$ & 2,0 & 0,3 & 2,8 & 0,35 & Gl(71),Fsp(28),Mag(1),Cpx(trace) \\
\hline LN 29 & 199 & 200 & 900 & $-10,82$ & 2,0 & 0,3 & 3,4 & 0,42 & Gl(58),Fsp(40),Mag(1),Cpx(1) \\
\hline LN 30 & 199 & 200 & 875 & $-11,28$ & 2,0 & 0,3 & 3,7 & 0,45 & $\mathrm{Gl}(54), \mathrm{Fsp}(44), \operatorname{Mag}(1), \mathrm{Bt}($ trace),Cpx(1),Tit(trace) \\
\hline LN 25 & 201 & 100 & 925 & $-10,41$ & 1,3 & 0,3 & 1,9 & 0,38 & Gl(66),Fsp(32),Mag(1),Cpx(1) \\
\hline LN 27 & 201 & 100 & 900 & $-10,85$ & 1,3 & 0,3 & 2,0 & 0,41 & Gl(60),Fsp(38),Mag(1),Cpx(1) \\
\hline LN 28 & 201 & 100 & 875 & $-11,32$ & 1,3 & 0,3 & 2,4 & 0,49 & Gl(51),Fsp(41),Mag(1),Bt(5),Cpx(2) \\
\hline LN $35^{\mathrm{h}}$ & 213 & 100 & 850 & $-11,80$ & 1,3 & 0,3 & & & Gl,Fsp,Mag,Bt,Cpx,Tit \\
\hline
\end{tabular}

n.a. Not analysed

trace: Mineral identified by SEM but with a very low $(<0.5)$ abundance.

a: $f \mathrm{O}_{2} 1 \log$ unit above the NNO oxygen buffer. The values given here were calculated with respect to the NNO oxygen buffer calibration of Huebner and Sato (1970). b: $\mathrm{wt} \% \mathrm{H}_{2} \mathrm{O}$ added: weight percent of water added to the rock powder.

c: $\mathrm{aH}_{2} \mathrm{O}^{*}$ : : initial water activities defined as: (wt $\%$ water added)/(wt $\%$ of water at saturation). See text for details.

$\mathrm{d}$ : wt $\%$ of water in the glass calculated using the wt $\%$ crystals present in the sample and the $\mathrm{wt} \% \mathrm{H}_{2} \mathrm{O}$ added to the capsule.

e: $\mathrm{aH}_{2} \mathrm{O}^{*}{ }_{\mathrm{gl}}$ : calculated water activity as : (wt\% water in the glass calculated)/( wt $\%$ of water at saturation). See text for details

f: Phase proportions (wt\%) calculated by mass balance. Mag: magnetite, Bt: biotite, Tit: titanite, Cpx: clinopyroxene, Fsp: feldspar, Gl: glass

g: Experiments highly crystallized and with a final water activity higher than the initial. See text for details.

h: Experiments highly crystallized and with small crystal sizes did not allow calculation of phase proportions. 
Table 3: Compositions and end-members of experimental magnetites (wt\%)

\begin{tabular}{|c|c|c|c|c|c|c|c|c|c|c|c|}
\hline Experiment & LN 7 & LN 9 & sd & LN 15 & LN 26 & sd & LN 31 & sd & LN 25 & sd & LN 27 \\
\hline $\mathrm{n}$ & 1 & 2 & & 1 & 4 & & 5 & & 5 & & 1 \\
\hline $\mathrm{SiO}_{2}$ & 0,13 & 0,49 & 0,09 & 0,09 & 0,11 & 0,03 & 0,31 & 0,20 & 0,28 & 0,18 & 0,29 \\
\hline $\mathrm{TiO}_{2}$ & 9,40 & 8,06 & 0,14 & 10,06 & 3,02 & 0,06 & 11,59 & 0,15 & 3,83 & 0,18 & 11,22 \\
\hline $\mathrm{Al}_{2} \mathrm{O}_{3}$ & 0,37 & 0,38 & 0,11 & 0,44 & 1,51 & 0,02 & 0,47 & 0,02 & 1,38 & 0,04 & 0,36 \\
\hline $\mathrm{MgO}$ & 0,79 & 1,10 & 0,05 & 1,45 & 3,62 & 0,04 & 1,59 & 0,06 & 3,32 & 0,10 & 1,78 \\
\hline $\mathrm{CaO}$ & 0,04 & 0,10 & 0,05 & 0,04 & 0,06 & 0,03 & 0,09 & 0,06 & 0,08 & 0,05 & 0,10 \\
\hline $\mathrm{MnO}$ & 2,37 & 7,70 & 0,33 & 3,47 & 2,22 & 0,07 & 0,89 & 0,03 & 2,42 & 0,09 & 1,20 \\
\hline $\mathrm{FeO}^{*}$ & 76,7 & 73,7 & 0,6 & 76,2 & 82,5 & 0,5 & 75,0 & 0,8 & 81,4 & 0,4 & 75,6 \\
\hline Sum & 89,8 & 91,5 & 0,8 & 91,7 & 93,1 & 0,6 & 89,9 & 0,6 & 92,7 & 0,4 & 90,6 \\
\hline $\mathrm{FeO}^{\mathrm{C}}$ & 34,7 & 28,6 & 0,3 & 33,7 & 26,2 & 0,3 & 37,0 & 0,2 & 27,2 & 0,2 & 36,3 \\
\hline $\mathrm{Fe}_{2} \mathrm{O}_{3}{ }^{\mathrm{C}}$ & 46,8 & 50,1 & 1,0 & 47,2 & 62,7 & 0,3 & 42,2 & 0,8 & 60,2 & 0,5 & 43,7 \\
\hline \multicolumn{12}{|l|}{ a.p.f.u. } \\
\hline $\mathrm{Fe}^{2+}{ }_{c}$ & 1,16 & 0,93 & 0,02 & 1,10 & 0,82 & 0,00 & 1,23 & 0,00 & 0,85 & 0,01 & 1,20 \\
\hline $\mathrm{Fe}^{3+}{ }_{\mathrm{c}}$ & 1,41 & 1,47 & 0,02 & 1,38 & 1,76 & 0,00 & 1,26 & 0,02 & 1,70 & 0,02 & 1,30 \\
\hline $\mathrm{Fe}^{3+}{ }_{c} /\left(\mathrm{Fe}^{2+}{ }_{c}+\mathrm{Fe}^{3+}{ }_{c}\right)$ & 0,55 & 0,61 & - & 0,56 & 0,68 & - & 0,51 & - & 0,67 & - & 0,52 \\
\hline ulvo & 24,9 & 16,9 & 0,9 & 25,3 & 4,3 & 0,1 & 34,9 & 0,9 & 6,0 & 0,4 & 32,1 \\
\hline Mt & 75,1 & 83,1 & 0,9 & 74,7 & 95,7 & 0,1 & 65,1 & 0,9 & 94,0 & 0,4 & 67,9 \\
\hline Mg-number & 1,7 & 2,8 & 0,1 & 3,2 & 9,9 & 0,1 & 3,1 & 0,2 & 8,8 & 0,2 & 3,6 \\
\hline Total $^{1}$ & 94,5 & 96,5 & 0,9 & 96,4 & 99,3 & 0,6 & 94,1 & 0,7 & 98,7 & 0,4 & 94,8 \\
\hline
\end{tabular}

sd: standard deviation

$\mathrm{n}$ : Number of electron microprobe analyses.

* Total iron as $\mathrm{Fe}^{2+}$

c: Denotes calculated by charge balance

a.p.f.u.: atoms per formula unit.

ulvo, Mt, magnetite end-members calculated as in Stormer (1983)

Mg-number $=100\left[\mathrm{Mg} /\left(\mathrm{Mg}+\mathrm{Fe}^{2+}{ }_{\mathrm{c}}\right)\right]$

1: Total after recalculating the proportions of $\mathrm{FeO}^{\mathrm{c}}$ and $\mathrm{Fe}_{2} \mathrm{O}_{3}{ }^{\mathrm{c}}$ 
Table 4: Compositions, and end-members of experimental alkali feldspars (wt\%).

\begin{tabular}{|c|c|c|c|c|c|c|c|c|c|c|c|c|c|c|c|c|c|c|c|c|c|c|}
\hline Experiment & N 2 & sd & N 4 & sd & N 11 & sd & N 22 & sd & N 19 & sd & N 14 & sd & N 6 & d & N 8 & sd & N 9 & $\mathrm{LN}$ & 23 & $\mathrm{LN}_{3}$ & N 29 & $\mathrm{LN}$ \\
\hline n & 6 & & 3 & & 2 & & 2 & & 2 & & 3 & & 3 & & 4 & & 1 & 1 & 1 & 1 & 1 & 1 \\
\hline $\mathrm{iO}_{2}$ & 65,6 & 0,4 & 66,6 & 0,4 & 64,9 & 02 & 64,7 & ? & 62,9 & 0,0 & 63,4 & 0,5 & 64,0 & 0,5 & 63,7 & 05 & 62,3 & 64,0 & 5,2 & 65,3 & 65,2 & 64,4 \\
\hline $\mathrm{TiO}_{2}$ & 0,07 & 03 & 08 & 06 & 09 & 01 & 0 & 0,00 & Oe & 00 & 35 & 09 & 30 & 18 & 6 & 2 & 28 & 5 & 9 & ,26 & ,38 & 0,40 \\
\hline $\mathrm{Al}_{2} \mathrm{O}_{3}$ & 19,33 & 0,55 & 18,89 & 0,31 & 20,22 & 0,18 & 19,43 & 0,04 & 19,47 & 0,22 & 19,60 & 0,10 & 19,42 & 0,10 & 19,32 & 0,16 & 19,25 & 19,68 & 20,00 & 19,45 & 19,18 & 19,59 \\
\hline eO* & 0,55 & 0,09 & 0,69 & 0,12 & 0,49 & 0,04 & 0,36 & 0,06 & 0,49 & 0,04 & 1,55 & 0,25 & 1,07 & 0,27 & 1,07 & 0,07 & 1,21 & 1,45 & 0,95 & 1,29 & 1,24 & 1,94 \\
\hline $\operatorname{lgO}$ & 0,07 & 0,05 & 0,19 & 0,19 & 0,01 & 0,01 & 0,02 & 0,01 & 0,00 & 0,00 & 0,16 & 0,05 & 0,29 & ,12 & 0,28 & 0,11 & 0,23 & 0,16 & 0,30 & 0,21 & 0,19 & 0,33 \\
\hline $\mathrm{aO}$ & 0,68 & 0,12 & 0,56 & 0,37 & 1,11 & 0,33 & 0,43 & 0,06 & 0,49 & 0,11 & 1,38 & 0,14 & 1,61 & 0,16 & 1,71 & 0,19 & 1,07 & 0,87 & 2,31 & 1,65 & 1,34 & 1,58 \\
\hline $\mathrm{Na}_{2} \mathrm{O}$ & 6,92 & 0,54 & 6,81 & 0,44 & 8,55 & 0,04 & 5,81 & 0,30 & 5,72 & 0,42 & 8,48 & 0,24 & 8,00 & 0,20 & 7,69 & 0,11 & 7,11 & 8,55 & 7,54 & 7,43 & 7,58 & 7,48 \\
\hline $\mathrm{K}_{2} \mathrm{O}$ & 6,41 & 0,85 & 6,99 & 0,49 & 4,47 & 0,57 & 7,35 & 0,12 & 7,99 & 0,49 & 3,45 & 0,07 & 4,29 & 0,17 & 4,15 & 0,13 & 5,18 & 3,96 & 3,20 & 3,33 & 4,39 & 3,99 \\
\hline Sum & 99,6 & 0,6 & 100,9 & 0,7 & 99,9 & 0,3 & 98,2 & 0 & 97,2 & 0,3 & 98,6 & 0,1 & 99,1 & 0,2 & 98,2 & 04 & 96,8 & 99,1 & 99,8 & 99,1 & 99,6 & 100,0 \\
\hline An & 27 & 0,60 & 2,67 & 1,81 & 5,06 & 1,61 & 2,16 & 0,30 & 2,38 & 0,49 & 6,62 & , & 7,59 & 0,63 & 3,32 & 0,86 & ,,32 & 4,13 & 11,69 & 8,66 & 6,61 & 7,95 \\
\hline $\mathrm{Ab}$ & 0,1 & 4,4 & 58,1 & 2,0 & 70,6 & 1,0 & 53,4 & 1,9 & 50,8 & 3,0 & 73,6 & 0,4 & 68,3 & 0,6 & 67,6 & & 4,0 & 73,5 & 69,0 & 70,5 & 67,6 & 68,1 \\
\hline Or & 36,6 & 4,7 & 39,2 & 2,9 & 24,3 & 2,6 & 44,5 & 1,5 & 46,8 & 3,5 & 19,7 & 0,8 & 24,1 & 1,3 & 24,0 & 1,0 & 30,7 & 22,4 & 19,3 & 20,8 & 25,8 & 23,9 \\
\hline
\end{tabular}

sd: Standard deviation

n: Number of analysis.

* Total Iron reported as $\mathrm{FeO}$

$A n=100[\mathrm{Ca} /(\mathrm{Ca}+\mathrm{Na}+\mathrm{K})] ; \mathrm{Ab}=100[\mathrm{Na} /(\mathrm{Ca}+\mathrm{Na}+\mathrm{K})] ; \mathrm{Or}=[100 \mathrm{~K} /(\mathrm{Ca}+\mathrm{Na}+\mathrm{K})]$. End members calculated as in Deer et al. $(1972)$. 
Table 5: Compositions and end-members of experimental clinopyroxenes (wt\%).

\begin{tabular}{|c|c|c|c|c|c|c|c|c|c|c|}
\hline Experiment & LN 21 & sd & LN 23 & LN 31 & sd & LN 25 & sd & LN 29 & LN 28 & LN 30 \\
\hline $\mathrm{n}$ & 3 & & 1 & 2 & & 3 & & 1 & 1 & 1 \\
\hline $\mathrm{SiO}_{2}$ & 49,9 & 0,6 & 49,2 & 47,8 & 0,1 & 48,4 & 0,5 & 49,0 & 49,7 & 50,1 \\
\hline $\mathrm{TiO}_{2}$ & 1,30 & 0,32 & 1,44 & 2,13 & 0,02 & 1,90 & 0,14 & 1,60 & 1,62 & 1,50 \\
\hline $\mathrm{Al}_{2} \mathrm{O}_{3}$ & 3,21 & 0,90 & 3,86 & 4,27 & 0,48 & 3,82 & 0,41 & 4,05 & 2,56 & 2,48 \\
\hline $\mathrm{MgO}$ & 12,8 & 0,8 & 11,3 & 11,7 & 0,3 & 12,8 & 0,3 & 11,7 & 12,7 & 12,6 \\
\hline $\mathrm{CaO}$ & 21,3 & 0,5 & 20,7 & 19,9 & 0,2 & 20,7 & 0,6 & 20,0 & 20,7 & 21,0 \\
\hline $\mathrm{MnO}$ & 0,88 & 0,04 & 1,04 & 0,79 & 0,01 & 0,75 & 0,05 & 0,89 & 1,03 & 0,98 \\
\hline $\mathrm{FeO}^{*}$ & 8,80 & 0,46 & 10,62 & 11,05 & 0,10 & 10,11 & 0,30 & 10,57 & 10,05 & 9,69 \\
\hline $\mathrm{Na}_{2} \mathrm{O}$ & 1,73 & 0,24 & 1,87 & 2,32 & 0,03 & 1,54 & 0,19 & 2,20 & 1,57 & 1,66 \\
\hline $\mathrm{K}_{2} \mathrm{O}$ & 0,0 & & 0,0 & 0,0 & & 0,0 & & 0,0 & 0,0 & 0,0 \\
\hline Sum & 100,0 & & 100,0 & 100,0 & & 100,0 & & 100,0 & 100,0 & 100,0 \\
\hline $\mathrm{wt} \%$ glass $^{\mathrm{a}}$ & 3,4 & & 5,2 & 7,2 & & 11,1 & & 6,3 & 10,2 & 5,7 \\
\hline $\mathrm{FeO}^{\mathrm{c}}$ & 1,65 & 0,56 & 3,72 & 1,02 & 0,57 & 2,37 & 0,79 & 2,39 & 3,42 & 3,18 \\
\hline $\mathrm{Fe}_{2} \mathrm{O}_{3}{ }^{\mathrm{c}}$ & 7,95 & 0,14 & 7,67 & 11,14 & 0,52 & 8,61 & 1,01 & 9,09 & 7,37 & 7,23 \\
\hline \multicolumn{11}{|l|}{ a.p.f.u. } \\
\hline $\mathrm{Fe}^{2+}{ }_{\mathrm{c}}$ & 0,05 & 0,02 & 0,12 & 0,03 & 0,02 & 0,07 & 0,02 & 0,07 & 0,11 & 0,10 \\
\hline $\mathrm{Fe}^{3+}{ }_{\mathrm{c}}$ & 0,22 & 0,00 & 0,22 & 0,31 & 0,01 & 0,24 & 0,03 & 0,25 & 0,21 & 0,20 \\
\hline $\mathrm{Fe}^{3+}{ }_{c} /\left(\mathrm{Fe}^{2+}{ }_{c} / \mathrm{Fe}^{3+}{ }_{c}\right)$ & 0,8 & & 0,6 & 0,9 & & 0,8 & & 0,8 & 0,7 & 0,7 \\
\hline En & 38,2 & 1,3 & 34,4 & 35,9 & 0,5 & 37,9 & 0,7 & 36,1 & 37,5 & 37,5 \\
\hline Fs & 14,7 & 1,2 & 18,2 & 19,0 & 0,4 & 16,8 & 0,4 & 18,2 & 16,7 & 16,1 \\
\hline Wo & 45,6 & 0,2 & 45,5 & 43,8 & 0,1 & 44,0 & 0,4 & 44,1 & 44,1 & 44,7 \\
\hline Mg-number & 86,2 & 2,3 & 70,6 & 90,2 & 0,8 & 81,2 & 0,9 & 79,7 & 74,7 & 76,0 \\
\hline
\end{tabular}

${ }_{w t} \%$ glass $^{\mathrm{a}}$ : Clinopyroxene compositions are re-calculated due to glass contamination (see text for details) and here we show the wt\% glass that was substracted from the original electron microprobe analysis. sd: Standard deviation.

$\mathrm{n}$ : Number of analyses.

* Total Iron reported as $\mathrm{Fe}^{2+}$.

c: Denotes calculated by charge balance. a.p.f.u.: atoms per formula unit. En, Fs, Wo: calculated as in Morimoto (1989).

Mg-number $=100\left[\mathrm{Mg} /\left(\mathrm{Mg}+\mathrm{Fe}^{2+} \mathrm{c}\right)\right]$. 
Table 6: Composition of experimental glasses (wt\%) normalized to $100 \%$ anhydrous basis.

\begin{tabular}{|c|c|c|c|c|c|c|c|c|c|c|c|c|c|c|c|c|c|}
\hline & LN 8 & sd & LN 7 & sd & LN 11 & sd & LN 12 & sd & LN 13 & sd & LN 14 & sd & LN 18 & sd & LN 17 & sd & LN 15 \\
\hline $\mathrm{n}$ & 2 & & 3 & & 4 & & 4 & & 5 & & 3 & & 5 & & 6 & & 4 \\
\hline $\mathrm{SiO}_{2}$ & 62,1 & 0,7 & 62,3 & 0,9 & 62,0 & 0,2 & 60,5 & 0,4 & 61,7 & 0,3 & 62,0 & 0,1 & 61,4 & 0,2 & 61,3 & 0,3 & 61,7 \\
\hline $\mathrm{TiO}_{2}$ & 0,45 & 0,02 & 0,51 & 0,04 & 0,46 & 0,03 & 0,54 & 0,02 & 0,46 & 0,04 & 0,51 & 0,02 & 0,69 & 0,02 & 0,74 & 0,01 & 0,57 \\
\hline $\mathrm{Al}_{2} \mathrm{O}_{3}$ & 20,2 & 0,1 & 20,1 & 0,4 & 20,6 & 0,3 & 20,7 & 0,3 & 20,3 & 0,1 & 20,1 & 0,3 & 20,2 & 0,1 & 20,2 & 0,2 & 20,3 \\
\hline $\mathrm{MgO}$ & 0,26 & 0,02 & 0,28 & 0,02 & 0,20 & 0,02 & 0,24 & 0,06 & 0,24 & 0,05 & 0,25 & 0,01 & 0,32 & 0,04 & 0,32 & 0,02 & 0,40 \\
\hline $\mathrm{CaO}$ & 0,71 & 0,02 & 0,87 & 0,06 & 0,56 & 0,08 & 0,60 & 0,05 & 0,82 & 0,27 & 0,60 & 0,05 & 0,89 & 0,07 & 0,92 & 0,03 & 1,09 \\
\hline $\mathrm{MnO}$ & 0,12 & 0,01 & 0,15 & 0,01 & 0,13 & 0,02 & 0,15 & 0,01 & 0,13 & 0,02 & 0,14 & 0,02 & 0,12 & 0,01 & 0,13 & 0,02 & 0,19 \\
\hline FeO* & 1,86 & 0,02 & 2,09 & 0,02 & 1,77 & 0,05 & 2,28 & 0,11 & 1,88 & 0,11 & 2,12 & 0,09 & 2,07 & 0,09 & 2,20 & 0,09 & 2,16 \\
\hline $\mathrm{Na}_{2} \mathrm{O}$ & 9,1 & 0,1 & 9,2 & 0,2 & 8,9 & 0,3 & 9,3 & 0,2 & 9,2 & 0,2 & 9,4 & 0,2 & 9,0 & 0,3 & 8,9 & 0,1 & 8,6 \\
\hline $\mathrm{K}_{2} \mathrm{O}$ & 5,2 & 0,7 & 4,6 & 0,6 & 5,4 & 0,4 & 5,7 & 0,5 & 5,2 & 0,5 & 4,9 & 0,1 & 5,3 & 0,4 & 5,3 & 0,5 & 5,0 \\
\hline Sum & 100,0 & & 100,0 & & 100,0 & & 100,0 & & 100,0 & & 100,0 & & 100,0 & & 100,0 & & 100,0 \\
\hline Original sum & 96,2 & 1,1 & 91,3 & 0,6 & 94,7 & 0,7 & 99,2 & 0,5 & 94,9 & 0,4 & 96,8 & 0,3 & 97,8 & 0,6 & 95,1 & 0,3 & 91,7 \\
\hline per-alkalinity & 1,0 & & 1,0 & & 1,0 & & 1,0 & & 1,0 & & 1,0 & & 1,0 & & 1,0 & & 1,0 \\
\hline $\mathrm{Na}_{2} \mathrm{O}+\mathrm{K}_{2} \mathrm{O}$ & 14,4 & & 13,8 & & 14,3 & & 15,0 & & 14,4 & & 14,3 & & 14,3 & & 14,2 & & 13,6 \\
\hline Mg-number & 19,9 & & 19,5 & & 16,8 & & 15,8 & & 18,3 & & 17,2 & & 21,8 & & 20,7 & & 24,8 \\
\hline
\end{tabular}

Table 6 (cont.): Composition of experimental glasses (wt\%) normalized to $100 \%$ anhydrous basis.

\begin{tabular}{|c|c|c|c|c|c|c|c|c|c|c|c|c|c|c|c|c|c|}
\hline & LN 5 & sd & LN 6 & sd & LN 1 & sd & LN 21 & sd & LN 23 & sd & LN 24 & sd & LN 26 & sd & LN 31 & sd & LN 25 \\
\hline $\mathrm{n}$ & 7 & & 5 & & 6 & & 7 & & 6 & & 6 & & 7 & & 6 & & 6 \\
\hline $\mathrm{SiO}_{2}$ & 61,3 & 0,4 & 60,5 & 0,4 & 60,8 & 0,4 & 61,5 & 0,3 & 61,4 & 0,3 & 61,6 & 0,1 & 61,3 & 0,2 & 61,7 & 0,2 & 61,3 \\
\hline $\mathrm{TiO}_{2}$ & 0,24 & 0,02 & 0,23 & 0,01 & 0,16 & 0,01 & 0,50 & 0,05 & 0,49 & 0,09 & 0,41 & 0,02 & 0,63 & 0,05 & 0,33 & 0,03 & 0,44 \\
\hline $\mathrm{Al}_{2} \mathrm{O}_{3}$ & 20,8 & 0,2 & 20,5 & 0,3 & 21,5 & 0,2 & 20,2 & 0,1 & 19,9 & 0,2 & 20,3 & 0,2 & 19,4 & 0,1 & 19,6 & 0,1 & 19,3 \\
\hline $\mathrm{MgO}$ & 0,16 & 0,03 & 0,25 & 0,10 & 0,07 & 0,01 & 0,22 & 0,01 & 0,26 & 0,05 & 0,19 & 0,02 & 0,34 & 0,02 & 0,24 & 0,03 & 0,30 \\
\hline $\mathrm{CaO}$ & 0,84 & 0,19 & 0,72 & 0,16 & 0,57 & 0,14 & 0,76 & 0,03 & 0,73 & 0,16 & 0,66 & 0,06 & 1,06 & 0,06 & 0,68 & 0,04 & 0,82 \\
\hline $\mathrm{MnO}$ & 0,14 & 0,03 & 0,15 & 0,04 & 0,12 & 0,04 & 0,15 & 0,03 & 0,16 & 0,05 & 0,15 & 0,02 & 0,17 & 0,04 & 0,19 & 0,04 & 0,16 \\
\hline $\mathrm{FeO}^{*}$ & 2,07 & 0,06 & 2,30 & 0,13 & 1,68 & 0,08 & 2,07 & 0,08 & 2,31 & 0,12 & 1,98 & 0,11 & 2,69 & 0,05 & 2,32 & 0,09 & 2,53 \\
\hline $\mathrm{Na}_{2} \mathrm{O}$ & 9,3 & 0,2 & 9,4 & 0,2 & 9,6 & 0,2 & 9,1 & 0,2 & 9,1 & 0,1 & 9,2 & 0,2 & 8,7 & 0,2 & 9,2 & 0,2 & 9,2 \\
\hline $\mathrm{K}_{2} \mathrm{O}$ & 5,1 & 0,1 & 5,9 & 0,2 & 5,4 & 0,1 & 5,5 & 0,1 & 5,7 & 0,1 & 5,5 & 0,1 & 5,7 & 0,1 & 5,7 & 0,1 & 5,8 \\
\hline Sum & 100,0 & & 100,0 & & 100,0 & & 100,0 & & 100,0 & & 100,0 & & 100,0 & & 100,0 & & 100,0 \\
\hline Original sum & 86,7 & 0,7 & 89,9 & 0,5 & 83,4 & 0,8 & 95,2 & 0,8 & 96,1 & 0,7 & 92,7 & 1,2 & 94,8 & 0,2 & 95,8 & 0,7 & 97,0 \\
\hline per-alkalinity & 1,0 & & 1,1 & & 1,0 & & 1,0 & & 1,1 & & 1,0 & & 1,1 & & 1,1 & & 1,1 \\
\hline $\mathrm{Na}_{2} \mathrm{O}+\mathrm{K}_{2} \mathrm{O}$ & 14,4 & & 15,3 & & 15,1 & & 14,7 & & 14,8 & & 14,7 & & 14,4 & & 15,0 & & 15,1 \\
\hline
\end{tabular}


All analyses are normalized to $100 \%$ anhydrous. Original totals before alkali correction are reported. sd: Standard deviation.

$\mathrm{n}$ : Number of analysis.

* Total iron reported as $\mathrm{Fe}^{2+}$.

per-alkalinity: $(\mathrm{Na}+\mathrm{K}) / \mathrm{Al}$ in mols 


$\begin{array}{ccccccccc}\text { sd } & \text { LN 16 } & \text { sd } & \text { LN 20 } & \text { sd } & \text { LN 22 } & \text { sd } & \text { LN 19 } & \text { sd } \\ & 5 & & 9 & & 4 & & 6 & \\ 0,1 & 61,6 & 0,1 & 61,1 & 0,2 & 62,4 & 0,1 & 60,9 & 0,2 \\ 0,02 & 0,44 & 0,03 & 0,63 & 0,03 & 0,20 & 0,02 & 0,26 & 0,07 \\ 0,1 & 20,7 & 0,2 & 20,2 & 0,1 & 21,3 & 0,1 & 21,8 & 0,2 \\ 0,03 & 0,28 & 0,02 & 0,54 & 0,03 & 0,08 & 0,02 & 0,11 & 0,04 \\ 0,07 & 0,73 & 0,05 & 1,21 & 0,03 & 0,39 & 0,08 & 0,35 & 0,09 \\ 0,06 & 0,15 & 0,02 & 0,15 & 0,04 & 0,12 & 0,04 & 0,18 & 0,03 \\ 0,06 & 1,91 & 0,07 & 2,56 & 0,07 & 1,55 & 0,02 & 1,85 & 0,12 \\ 0,1 & 8,9 & 0,1 & 8,6 & 0,2 & 8,9 & 0,1 & 9,6 & 0,2 \\ 0,1 & 5,4 & 0,1 & 5,0 & 0,1 & 5,0 & 0,1 & 5,0 & 0,1 \\ & 100,0 & & 100,0 & & 100,0 & & 100,0 & 0,0 \\ & & & & & & & & \\ 0,1 & 93,1 & 0,2 & 93,1 & 0,4 & 91,1 & 0,2 & 91,5 & 0,5 \\ & 1,0 & & 1,0 & & 0,9 & & 1,0 & \\ & 14,2 & & 13,6 & & 14,0 & & 14,5 & \\ & 20,8 & & 27,4 & & 8,4 & & 9,4 & \end{array}$

$\begin{array}{ccccccccc}\text { sd } & \text { LN 29 } & \text { sd } & \text { LN 27 } & \text { sd } & \text { LN 28 } & \text { sd } & \text { LN 30 } & \text { sd } \\ & 4 & & 5 & & 6 & & 5 & \\ 0,2 & 61,4 & 0,1 & 60,9 & 0,1 & 60,9 & 0,1 & 61,5 & 0,3 \\ 0,02 & 0,31 & 0,02 & 0,39 & 0,02 & 0,36 & 0,02 & 0,33 & 0,01 \\ 0,1 & 19,8 & 0,1 & 19,9 & 0,1 & 19,8 & 0,1 & 19,6 & 0,2 \\ 0,03 & 0,21 & 0,02 & 0,25 & 0,01 & 0,24 & 0,05 & 0,22 & 0,06 \\ 0,10 & 0,61 & 0,02 & 0,69 & 0,21 & 0,62 & 0,10 & 0,70 & 0,10 \\ 0,04 & 0,14 & 0,03 & 0,20 & 0,05 & 0,16 & 0,03 & 0,18 & 0,03 \\ 0,10 & 2,30 & 0,06 & 2,50 & 0,09 & 2,55 & 0,07 & 2,34 & 0,11 \\ 0,2 & 9,5 & 0,1 & 9,4 & 0,2 & 9,5 & 0,1 & 9,3 & 0,3 \\ 0,1 & 5,7 & 0,1 & 5,8 & 0,1 & 5,8 & 0,1 & 5,8 & 0,1 \\ & 100,0 & & 100,0 & & 100,0 & & 100,0 & \\ & & & & & & & & \\ 0,4 & 95,6 & 0,7 & 95,9 & 0,5 & 95,5 & 0,4 & 94,5 & 0,4 \\ & 1,1 & & 1,1 & & 1,1 & & 1,1 & \end{array}$


